\title{
International Law and the United States Role in
}

\author{
Viet Nam: A Response to Professor Moore
}

\section{Richard Falk $†$}

In the best traditions of scholarly debate Professor John Norton Moore has taken sharp and fundamental issue with the legal analysis of the United States' role in the Viet Nam War that I outlined in a previous issue of the Yale Law Journal. ${ }^{1}$ Professor Moore has not persuaded me either that my approach is "simplistic" or that its application to Viet Nam is "unsound," but he has identified weaknesses and incompletenesses in my earlier formulation. " In addition, he has developed an alternative legal framework for assessing foreign intervention in violent struggles for the control of a national society. My objective in responding is to clarify the contending world order positions that each of us espouses. Although Professor Moore affirms and I deny the legality of the United States' military role in Viet Nam, the main center of intellectual gravity in this debate is less passing judgment on the grand legal issue of American presence (at this stage, a legalistic exercise), than it is assessing the policy implications of the Viet Nam precedent for the future of international legal order.

Professor Moore and I agree that international law can serve as a significant source of guidance to the national policy-maker in the area of war and peace. International law implies a process of decision incorporating perspectives that tend to be left out of account when government officials develop national policies solely by considering capabilities, strategies, and current foreign policy goals that are designed to maximize the short-run "national advantage." International law contains rules and standards rooted in the cosmopolitan tradition of a community of nations, whereas foreign policy tends to be rooted in the more particularistic traditions of each state. The future of world legal order may depend to a great degree on the extent to which the decision process relied upon in principal states to form foreign policy can come increasingly to incorporate more cosmopolitan perspectives.

$\dagger$ Milbank Professor of International Law, Woodrow Wilson School of Public and International Affairs; Faculty Associate, Center of International Studies, Princeton University; B.S. 1952, University of Pennsylvania; LL.B. 1955, Yale University.

1. Falk, International Law and the United States Role in the Fiet Nam War, 75 YAt. L.J. 1122 (1966).

2. Pages in parentheses in this article refer to Professor Mloore's article. 
International law has itself evolved through a process of decision in which national policies governing the appropriate uses of military power have been clarified by the assertion of adverse national claims buttressed by supporting explanations and rationale. This process is especially germane whenever the relevance of the rules to the claims of states is challenged on a legal basis, as it has been since the outset of major United States involvement in Viet Nam. The claims of governments to use or resist coercion serve as precedents for future claims and imply commitments to develop a certain kind of international legal system deemed beneficial both to the countries directly concerned and to the wider community of all states. My disagreement with Professor Moore centers upon the degree of discretion that international law presently accords to states with respect to the use of force in an international conflict resembling the one that has unfolded in Viet Nam in the years since 1954 and extends to the sorts of considerations (and their relative weight) that should have been taken into account in the decisions that led to the American military involvement at the various stages of its increasing magnitude. I would contend that the American military involvement resulted from a series of geo-political miscalculations, as well as from a process of decision insensitive to world order considerations.

The Viet Nam conflict demonstrates the harmful consequences for the control of international violence that can arise from contradictory national interpretations of what constitutes "aggression" and what constitutes permissible acts of "defense." Given the decentralized character of international society, it becomes more important than ever, in my view, to inhibit unilateral recourse to violence arising from contradictory and subjective national interpretations of a conflict situation. The war in Viet Nam illustrates a situation in which it is "reasonable" for each side to perceive its adversary as guilty of unprovoked aggression. ${ }^{\mathrm{B}}$ The potential for military escalation that follows from each side doing whatever it deems necessary to uphold its vital interests is an alarming freedom to grant governments in the nuclear age. My approach to these world order issues presupposes the central importance of establishing binding quasi-objective limits upon state discretion in international

3. For a persuasive account by a psychologist as to why the North Vietnamese perceive the United States' role in Viet Nam as aggression see White, Misperception of Aggression in Vietnam, $21 \mathrm{~J}$. INT'L AFF. 123 (1967); for a more fully documented presentation of the same position by the same author see White, Misperception and the Vietnam IVar, 22 J. SOcial Issues 1 (1967). The prospect of mutually contradictory perceptions of aggression held in good faith is central to my argument against Professor Moore's approach to world order problems. He takes no account of the reality or hazard of such misperception. 
situations in which such contradictory inferences of "aggression" are characteristic. I would argue, also, that the whole effort of international law in the area of war and peace since the end of World War I has been to deny sovereign states the kind of unilateral discretion to employ force in foreign affairs that the United States has exercised in Viet Nam. ${ }^{4}$

Professor Moore appears content to endorse virtually unfettered sovereign discretion. In the role of a disinterested observer, he purports to pass judgment on the legal status of a contested claim to use force. Professor Moore sets forth a certain conception of world order that he posits as crucial for human welfare, and then proceeds to examine whether the claim to use force in the particular situation of Viet Nam is compatible with it. Every national decision-maker is expected to engage in the same process of assessment. But no account is taken of the serious problems of auto-interpretation that arise when recourse to force is contemplated or carried out in inflamed international settings. These problems arise because each side tends toward a self-righteous vindication of its own contentions and an equally dogmatic inattention to the merits of the adversary's position. Professor Moore's approach recalls the natural law tradition in which the purported deference to the normative restraints operative upon the behavior of a Christian prince turned out in practice to be little more than a technique of post hoc rationalization on the part of a government and its supporters. Surely, his analysis fails to accord reciprocal empathy to the adversary's reasonable perceptions as to who is responsible for what in Viet Nam. In fact, Professor Moore's endorsement of America's military role is neither widely nor wholeheartedly shared among states normally allied with the United States.

It seems plain enough that Communist-oriented observers would regard the air strikes by the United States against North Viet Nam as unprovoked "aggression." Suggestions have even been made by more militant opponents of the United States' war actions that the passive

4. For a concise history of these efforts see Q. Wrigrt, THe Role of International Lavi IN THE ELMINATION OF TVAR (1961).

5. Anthony Lewis has summarized the situation in concise and moderate terms: "To go into the reasons for West European attitudes toward Vietnam would requirc rehearsing all the arguments about America's role there. Suffice it to say that only the British Government has had much favorable to say about American policy in Victnam. No European country has a single soldier there. Mfuch of the public on the Continent, righty; or not, see the situation as that of a huge power over-rcacting." Lewis, IWhy Humphrey Got That Abuse in Europe, N.Y. Times, April 16, 1967, § 4, ac 4, col. 4. Even the British Government has disassociated itself through a formal statement by her Prime Mlinister from United States bombing in June of 1966 of oil installations in Fanoi and Haiphong. For text of Mr. Wilson's statement sce Brmst Record, No. 12, July 14, 1966, Supp. 
role of the Soviet Union amounts to "appeasement" of the United States and that it is the Soviet Union, not the United States, that should heed the lesson of Munich. ${ }^{6}$ Professor Moore's emphasis on the discretion of the United States to furnish military assistance to Saigon needs to be supplemented by a consideration of what military assistance it would be reasonable for the Soviet Union and China to give to Hanoi; would not North Viet Nam be entitled to act in collective self-defense in response to sustained, large-scale bombing of its territory? And what limits could be legally placed on its exercise of self-defense other than those self-imposed by prudence and incapacity?

If we examine the war in Viet Nam from the perspective of North Viet Nam and with the same deference to self-determined reasonableness that Professor Moore confers upon the United States Government then it seems clear that the failure of the war to reach global proportions has been a consequence of Soviet and Chinese restraint (or incapacity); that is, Moore's world order position seems to legalize almost unlimited escalation by adversaries that perceive an ally as a victim of "aggression," even though that perception is not vindicated by any wider community determination and even though disinterested and reasonable men disagree as to who did what to whom. My earlier classification of international conflict into three broad categories is based on the need to avoid the anarchic consequences of adversary perception by fixing arbitrary but definite legal limits upon divergent interpretations of the rights and duties of national governments that find themselves involved in Viet Nam-type situations. ${ }^{7}$

Perhaps my position can be clarified by showing in a preliminary way why I reject the analogy between Viet Nam and Korea, an analogy that Professor Moore invokes to argue that similar defensive measures are appropriate in the two settings. ${ }^{8}$ If the facts in Viet Nam are as

6. See, e.g., a passage from an editorial appearing in the French intellectual journal Les Temps Moderne: 'The lack of clarity, the prudent policy of 'wait and sce' are the tombs of the Socialist and revolutionary movement; they pave the way for other disasters just as surely as nonintervention against Spanish Fascism in 1936 set the stage for 1910 and what followed. But the parallel extends beyond the Spanish Civil War; it includes the capitulations that preceded and followed the Munich Agreements.

"The United States is convinced that the Soviet Union will desist from any test of strength until the end." The editorial goes on to call for "Socialist counter-escalation" by means of Soviet rocket strikes at United States air and naval installations in the Pacific area. Affirmative: $A$ Deliberate Risk, translated and reprinted in 12 ATLAs, Nov. 1966, at $19,20$.

7. The basic rationale is set forth in Falk, supra note 1, at 1122-28. E.g., the Unitcd States is reported to have criticized the United Arab Republic for its attacks on Saudl Arabian border towns in the course of the struggle waged between the rival Yemeni factions for control of the Yemen. See N.Y. Times, May 17, 1967, at 1, col. 7.

8. There are other significant differences, including a war ending in 1954 for control 
Professor Moore and the United States Government contend, then it might be true that North Viet Nam is guilty of a covert equivalent of the aggression that was attempted overtly in 1950 by North Korea. ${ }^{\circ}$ But the assessment of the facts in Viet Nam is subject to multiple interpretations by reasonable observers in a way that the facts in Korea were not. Only the Communist states argued seriously against the conclusion that North Korea was an aggressor. Her overt military attack was suffciently clear to permit a global consensus to form in support of defensive action by South Korea. In contrast, the obscurity of the conflict in Viet Nam generates widespread disagreement outside the Communist world as to whether either side can be termed "the aggressor," and impartial observers as august as the Secretary General of the United Nations $^{10}$ and the Pope ${ }^{11}$ have repudiated any interpretation of the war

of the entire country, election provisions to translate this military outcome into political control at a time certain (1956), and a central government in Saigon that did not offer much prospect of governing South Viet Nam in any stable fashion cven apart from Com. munist harrassment. Part of the relevant background is the demonstrated competence of Ho Chi Minh to govern Viet Nam in an effective manner, a competence evident cven in the writings of those who are hostile to Communism and opposed to reunifieation under Hanoi's control. The capacity to govern territorial units effectively in the areas of the world most vulnerable to domestic trauma is itself a valuable constituent of the sort of international stability that the United States aspires to achicic for the Afro-Asian world. The background of Vietnamese social and cultural history also supports strongly the inference of an autonomous Vietnamese spirit, one that above all would resist any effort at domination by the Chinese. Ho Chi Afinh's reasonableness was demonstrated in the period after World War II when he co-operated successfully with non-Communist factions in Viet Nam and made notable concessions to the French in exchange for an acknowledgment of his leadership of an independent Republic of Viet Nam; the French later re. pudiated these negotiations and the first Indochina WWar was born. For the sense of bac:ground see E. HAMIMER, THE STRUGGLe FOR INDO-ChINA 1940-1955 (1955); L. BOD.4R, THE

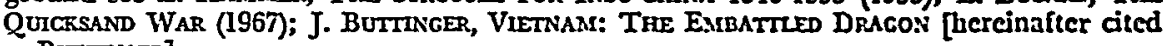
as BuTtINGER].

Recently these points have also been made effectively in Farer, The Enemy-Exploring the Sources of a Foreign Policy, ColundalA UNIversity Forum, Spring 1967, at 13; see especially his quotation of the remark of Walter Robertson, Assistant Secretary of State for Far Eastern Affairs (an anti-Communist of such extreme character as to antagonize Anthony Eden because of his "emotional" approach): "If only Ho Chi Minh vere on our side ve could do something about the situation. But unfortunately he is the enemy." Id. 13 .

9. It is important, however, to appreciate the degree of ambiguity that necessarily inheres in the context of covert coercion unless the foreign state proclaims its aggressive design, as has the United Arab Republic in relation to Israel. Without such a proclamation, one never made by North Viet Nam, the attribution of motives is speculative and unconvincing, especially if the assumed motives are relied upon to justify major responsive violence. In Korea, it was North Korea that justified its recourse to oxert coercion by vague and unsupportable allegations that South Korea was planning to attack North Korea.

Bernard Fall commenting on the assertion "that North Victnamese infiltration into South Viet Nam is the equivalent of the North Korean invasion of the ROK" writes that the comparison "omits the embarrassing fact that anti-Dicm guerrillas vere active long before infiltrated North Vietnamese elements joined the fray." B. FALI, Tite Two VIETNasis 345 (2d rev. ed. 1967).

10. There are many indications of Thant's position on the matter. E.g., N.Y. Times, June 21, 1966, at 1, col. 5 .

11. Cf. Pope Paul's Encyclical on Peace of Sept. 19, 1966, text in N.Y. Times, Sept. 20, 
in Viet Nam that identifies North Viet Nam as the aggressor. France
has openly repudiated the United States' conception of the war, and
neutral public opinion at home and abroad is, to say the least, sharply
split. ${ }^{12}$ This situation of dissensus sharply distinguishes Viet Nam from

1966, at 18, col. 2. For example, taking account of the tradition of indirect rhetoric, the following passage was written with obvious application to war in Vict Nam: "We cry to them in God's name to stop. Men must come together and offer concrete plans and terms in all sincerity. A settlement should be reached now, even at the expense of some inconvenience or loss, for it may have to be made later in the train of bitter slaughter and involve great loss." The following sentence also confirms the emphasis upon the non-condemnation of either side as aggressor: "Now again, therefore, we lift up our voice, "with piercing cry and with tears' (Hebrews, v, 7), very earnestly beseeching those who have chargc of the public welfare to strive with every means available to prevent the further spread of the conflagration, and even to extinguish it entirely." More recently, Pope Paul VI has specifically urged the cessation of all forms of violence throughout Viet Nam. N.Y. Times, May 25,1967 , at 4 , col. 4 .

12. I regard the unprecedented intensity, range, and character of the protest movement directed at the American military involvement in Viet Nam to be significantly relevant to an appraisal of the status of United States claims under international law. The standards governing the use of force in world affairs reflect moral attitudes toward those occasions upon which it is appropriate to rely upon military power. This wide. spread protest phenomenon reflects the moral conviction of people throughout the world that the United States is guilty of aggressive war in Viet Nam; such a moral conviction is not inconsistent with the democratically-based support for the war given by the Ameri. can public, according priority to winning a war that should not have been fought rather than to accepting the need to acknowledge error. Edwin $O$. Reischauer, the former American Ambassador to Japan, has well stated this orientation toward the war taken by those who continue to give their support, however, grudgingly, to the American cftort in Viet Nam:

There is not much agreement in this country about the war in Vietnam, except that it is something we should have avoided. We are paying a heavy price for it-in lives, in national wealth and unity, and in international prestige and influence. The best we can hope for from the war is sufficient peace and stability to allow that small and weak country to get painfully to its feet at last; the worst is a nuclear conflict too horrible to contemplate. Reischauer, What We Should do Next in Asia, Look, April 4, 1967, at 21.

It may also be well to ponder the following paragraph from the editorial columns of The New Reublic:

Simultaneously [with other beneficial international policies of the United States] Mr. Johnson is pushing the Vietnam war-which is a disastrous thing. It is all very" well to say the country backs him, Governor Romney being the latest "me too" recruit. Yes, the polls show the public supports continued bombing, 67 percent. But a second series of polls shows only 37 percent backing Mr. Johnson's handling of the war. Reconciling these two views isn't really very difficult. The public loathes the war. It doesn't want defeat, but it wants out. The two moods conflict. It backs the bombing on the simplistic ground that that will end the war quickly. And it is taking out its resentment for the war dilemma consciously or unconsciously by making Mr. Johnson the scapegoat. THE NEw REPUblic, April 22, 1967, at 2.

Among those aspects of the protest against participation in the war that are most legally notable have been the efforts, never made in the Korean context to nearly the same cx. tent, to obtain a determination by domestic courts that participation in the Viet Nam war is tantamount to the commission of a war crime; the reasoning being that the Gcrman and Japanese war crimes trials conducted after World War II concluded that an individ. ual is criminally accountable for participation in a war of aggression (i.e., an illegal war) regardless of whether or not he is carrying out the orders of his government. There are also many cases now arising for the first time of "selective conscientious objection" in which individuals subject to the draft are claiming exemption not because thcy are opposed to war in general but because they oppose the Viet Nam war in particular on grounds of conscience. A dramatic instance of litigation to test whether there is a legal 
Korea and strongly suggests that the discretion to act "defensively" requires some source of restraint more dependable than the wisdom of the belligerent states. ${ }^{13}$

The presence or absence of a consensus has considerable bearing on the legal status of a contested claim to use force in international society. ${ }^{14}$ The Charter of the United Nations purports to restrict the unilateral discretion of states to use force to resolve international conflicts. ${ }^{15}$ In cases where a claim of self-defense is made and challenged,

right of conscientious objection to a particular war has been filed. Capt. Dale E. Noyd of the Air Force Academy in the Federal District Court of Colorado in Denver. N.Y. Times, April 20, 1967, at 5, col. 3; for a description of the litigation see Crvm Linemries, No. 245, April 1967, at 1, 5. For a continuing description of evidence supporting the invocation of selective conscientious objection in the Viet Nam context see the responsible reporting of the weekly British newspaper Peace News, the bi-monthly American magazine VIET REPORT, or almost any French organ of opinion (left, right, or center). For one (among many) vivid account of the horrors inflicted on Vietnamese society see Arccarthy; Report from Vietnam II: The Problems of Success, N.Y. REview of Books, MIay 4, 1907, at 4.

Furthermore, for the first time during a period of war a group of intermational lavjers have gone on record against their own government to contend that the United States military involvement in Viet Nam is "illegal," and constitutes a violation of both international law and the U.S. Constitution. Consultative Councul of TIE Laivers"

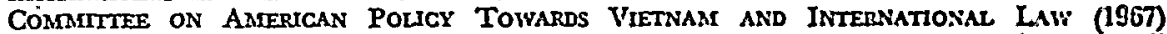
[hereinafter cited as Consultatrve CouncIL]. The members of the Consultative Council are R. J. Barnet, R. A. Falk (Chairman), John H.E. Fried (Rapporteur), John H. Herz, Stanley Hoffmann, Wallace MicClure, Saul H. Mendlovitz, Richard S. Míller, Hans J. Morgenthau, William G. Rice, and Quincy Wright.

Also for the first time since World War II there has been proposed a war crime tribunal to pass judgment on the United States role in Viet Nam and on the criminal responsibility of its President of course, Bertrand Russell's tribunal is a juridical farce, but the fact that it is plausible to contemplate such a proceeding and to obtain for its tribunal several celebrated individuals bears witness to the general perception of the var. For Jean-Paul Sartre's explanation of why he has agreed to serve as a judge on the Russcll tribunal sce Sartre, Imperialist Morality, 41 NEw LEFT REview 3 (1967).

See also Senate Republican Policy Committee, Blue Book on Viet Nair (MIay 1, 1967); for the text of its principal conclusions questioning the entire basis of the war see excerpts from G.O.P. Paper on TVar, N.Y. Times, May 2, 1967, at 10, col. 3.

13. The vagueness of the justification is accentunted in consequence by the gradual evolution of "the commitment" What started off in Viet Nam as a reluctant and indircet involvement that needed no special justification was successively widened and deepened until the involvement itself became the principal justification. With over 400,000 Amcricans fighting in Viet Nam and with casualties continuing to mount, there is a sense that the American effort must not be in vain; the consequence is an apparently irrerersible government commitment to use military means to accomplish a political objective-namely, to defeat the Vietcong insurrection, without according any governmental legitimacy to the N.L.F.

14. The relevance of an international consensus to the legality of contested national action is considered in Falk, On the Quasi-Legislative Competcnee of the General Assembly, 60 AM. J. INT'L L. 782 (1966). And see the dissenting opinion of Judge Tanaks in the South West Africa Cases for an analysis in the setting of human rights of the shift from an emphasis upon sovereign autonomy to community solidarity in determining the character of international legal obligations. Judgment in the South West Africa Cases, July 18, 1965, [1966] I.C.J. 248, 292-94.

15. For a helpful exposition of the restrictive intention of the relevant Charter provisions see Henkin, Force, Intervention, and Neutrality in Contemporary Internalional Law, 1963 Proc. AM. SOC'Y INr'L L. 147; P. JEsSUP, A MODERy LAW of NATIONS 165.67 (1948); in this context it is not necessary to contend that Article 51 restricts traditional self-defense in terms of some rigid conception of "armed altad;, but only that the dis- 
the burden of justification is upon the claimant. It is always possible to argue that a use of force is "defensive" and that it promotes world order by inhibiting "aggression." Therefore, fairly clear community standards would be needed to assure that what is called "defensive" is defensive; in the absence of clear community standards it becomes important to allow international institutions to determine whether recourse to "defensive force" is justified by a prior "armed attack." Where there are no generally accepted objective standards and where rivals put forward contradictory factual interpretations it becomes difficult or impossible to mobilize a consensus in the international institutions entrusted with the maintenance of peace and security. ${ }^{10}$ Viet Nam presents such a situation of uncertainty and institutional paralysis. What restraints upon sovereign discretion to use force remain relevant? 'The appraisals of disinterested international civil servants, especially the

cretion of states to have recourse to force in self-defense is subject to justification and review. See, e.g., D. BoweTr, SELF-Defrence in INTERNATIONAL LAw 216-18, 241, 244.45, 261 (1958), emphasizing the importance of restricting discretionary recourse to self-defensc, especially on a collective basis, in the Viet Nam-type situation.

16. Even a defensive alliance such as SEATO has been unable to maintain its solidarity in the face of the disputed facts and policies generated by the Viet Nam conflict. France and Pakistan, both Members, refuse to give their assent to SEATO's endorsement of the American "interpretation" of the war in Viet Nam. It should be recalled that SEATO was a pact among anti-Communist states determined to resist the coercive spread of Asian Communism, including explicitly its spread to South Viet Nam; the non-Communist neutralist states of Asia are, without exception, even more dubious about the American "interpretation." The relevant point is that a claim to be acting in a "defensive" way when force is used against a foreign society has no legal status unless it is supported by some kind of international authorization that commands respect; otherwise it is merely a contention by an adversary determined to make unilateral use of military power against a foreign society.

A study of South Viet Nam attitudes suggest that even in the late phases of the war in Viet Nam the people of the country reject the official United States version of "defensive" action. The poll was conducted for Columbia Broadcasting Company by Opinion Research Corporation, a respected professional polling outfit, consisted of an interview of 1,545 persons living in five major cities, 55 hamlets, and was limited to civilians of voting age living in "secured areas," those not under Vietcong control: The poll took place between November 24,1966 and February 1,1967 . When asked who was responsible for continuing the war 31 per cent blamed the Vietcong and only 12 per cent blamed the Government of North Viet Nam; when asked whether bombing should be continued against villages suspected of containing the Vietcong 46 per cent favored an end to bomb. ing while 37 per cent wanted it continued; when asked whether to stress negotiations with North Viet Nam or to extend military operations to North Viet Nam 60 per cent favored more emphasis on negotiations whereas only about 14 per cent favored increased military action; and finally when asked whether they favored reunification after the end of the war 83 per cent were reported in favor and only 5 per cent opposed. N.Y.Times, March 22, 1967, at 10, col. 7. The remarkable thing about this poll is that among strong anti-Communist South Vietnamese ( 65 per cent blamed the Communist side for the continuation of the war and only 5 per cent blamed the anti-Communist side) exposed primarily to government propaganda there still appears to be a rejection of the American idea that the war is a consequence of "aggression from the North." The attitudes on reunification also sharply question the Saigon-Washington insistence on separate sovereighty for the North and the South. See the similar character of an anti-Communist, anti. American interpretation of the war by a distinguished Buddhist in South Vict Nam, T. Hank, Vietnam Lotus in a SEa of Fire (1967). 
Secretary General of the United Nations, are distinctly relevant in this setting. The Secretary General contributes an impartial perspective and can, as U Thant has chosen to do with respect to Viet Nam, delineate the character of reasonable behavior by the adversary parties. ${ }^{17}$ Normally such an official will refrain from judging the behavior of the participants in a conflict that cannot be handled by agreement in the political organs. The persistent refusal of the United States to comply with U Thant's proposals is indicative of its unilateral approach to the determination of the legitimacy of a contested use of international force. ${ }^{18}$ The essence of a law-oriented approach to the use of force is to

17. The essential aspect of a legal settlement is the search for impartial sources of decision. It is the impartial decision-maker that is in the best position to assess the relative merits of adversary positions. This does not assure correct or just decisions in any particular instance, but merely that there will be a legal quality for the decision. The Secretary General of the United Nations is the most authoritative impartial decision-maker in the international system, especially in relation to Arembers of the United Nations. To deny his role or to ignore his recommendation is to subordinate the process of impartial decision to the process of unilateral decision, tending thereby to rely on power rather than law to shape the outcome of controversy.

18. The opposition of the United States to the efforts of $U$ Thant to work for a settlement are summarized in Axerican Friends Service Comaittee, Pesce in Vietiand 50-52 (1966); F. Schuraiann, P. Scott, \& R. Zelnik, The Polutics of Escalation in Vietsasd $135-38$ (1966). On June 20, 1966, U Thant made a three-point proposal for ending the war in Viet Nam:

(1.) Unconditional cessation of bombing in North Viet Nam;

(2.) Scaling down of military operations in South Viet Nam;

(3.) Inclusion of the National Liberation Front in any proposed negotiations.

N.Y. Times, June 21, 1966, at 1, col. 5. The failure of the United States to accept this proposal, consisting according to $U$ Thant of those steps that "alone an create the condi. tions" leading to a peaceful settlement, is indicative of its unilateral approach to the use of military power in Viet Nam. U Thant, as Secretary General, represents the voice of the international community, a voice that deserves to be heeded especially by a Great Power using its military power to overwhelm a small state. The role of the Secretary General in identifying reasonable conduct for parties in conflict is especially great when the political organs have failed to discharge their responsibility to maintain international peace and security. As in other dealings with the United Nations during the Viet Nam war the United States has made pro forma gestures indicating its acoeptance of the Secretary General's role. See, e.g., Arthur J. Goldberg's letter to U Thant in which it is said that "the United States Government will cooperate fully with jou in getting such discussion started promptly [on ending the war] and in bringing them to a successful com. pletion." Text, N.Y. Times, Dec. 20, 1966, at 6, col. 4. The United States will cooperate fully provided that it does not have to alter its belligerent and political posture. U Thant is setting forth his conception of reasonable preconditions for peace talls. What does our cooperation entail if it does not lead to an acceptance of these preconditions? Our noncooperation with $U$ Thant is heightened by the fact that the preconditions he describes are those that seem calculated to bring the war to an end and to initiate negotiations on a reasonable basis that corresponds to the domestic balance of forces. Negotiations would proceed on an unnatural basis if either the suspension of bombing was conditional-it would be a club of death suspended by a powerful state over the destinies of a vieas one-or the N.L.F. was not accorded some degree of legitimacy as a political force in South Viet Nam of a character equal to that of the Saigon regime. The insistence on nonrecognition is part of the effort to negotiate as if the N.L.F. were a creature of North Viet Nam rather than a political entity with a reality of its own. President Johnson has often repeated the idea that during the negotiations "the Vietcong will have no difficulty having their views heard," but this is not a very satisfactory assurance for an insurgent faction that has fought for over a decade to control South Viet Nam. Transcript of President's 
submit claims to the best available procedures for community review and to restrict force to the levels authorized. ${ }^{19}$

A second kind of restraint in a situation of ambiguity is to confine violence within existing international boundaries. The decision by the United States to bomb North Viet Nam and to take military action in the territory of Laos and Cambodia is further disregard for available limits upon the self-interpretation of legal rights. ${ }^{20}$ It is true that the United States is not yet using all the military power at its disposal against North Viet Nam, but such restraint is itself based on the exercise of discretion rather than upon deference to community procedures or to quasi-objective standards of limitation. ${ }^{21}$

News Conference on the Guam Parley, N.Y. Times, March 22, 1967, at 11, col. 3. It does not make the consent of the N.L.F. an ingredient of settlement, nor does it give to the N.L.F. any of the formal prerogatives of the Saigon regime. In effect, the civil war is ended not as a stalemate, but as a victory for the government side as it remains the sole constituted political élite.

19. We associate the intervention of law in human affairs with the role of the third. party decision-maker who is entrusted with the task of sorting out adversary contentions. International society as decentralized often successfully works out the content of rcasonableness through action and interaction of adversary parties, provided the issucs at stake are not vital to national security or national honor. In the context of force, however, the differential of power between adversaries of unequal strength influences their degrce of flexibility in responding to counter-claims; the differences between the results of adversary interaction and of impartial third-party judgment are likely to be pronounced. The sub. sitution of law for force in any social order involves, then, the gradual replacement of the ideology of self-help by that of third-party judgment. Perhaps, the clearest jurisprudential discussion of the limits of law in a decentralized political system is contained in H. KELSEN, Principles of International Law 3-87 (2d rev. ed. Tucker 1966).

20. Both sides have violated "the sovereignty" of Laos and Cambodia, but the United States has frequently bombed infiltrators and supply lines within the territory of both states, thereby expanding further the extra-national scope of violence beyond South Vict Nam. See Mansfield, et al., Report to Senate Foreign Relations Comm., 89th Cong., 2d Sess., The Vietnam Conflict: The Substance and the Shadow 8.10 (Comm. Print 1966) [hereinafter cited as ThE MANSFiELd REPORT]. An equivalent action by North Vict Num or the Soviet Union would be to attack the United States air bases in Thailand. Such an expansion of the arena of combat would move the conflict dramatically closer to the threshold of general warfare. It is important to emphasize that the limited scope of the war in Viet Nam is a consequence of the failure of the Soviet Union and China to takc equivalent action on behalf of Hanoi; such a failure is especially important in view of the United States demand that Hanoi take equivalent action in exchange for an end to bombing. See note 27 infra.

21. The United States reserves the discretion to decide for itself the degrec of military force that it requires to secure North Viet Nam's acquiescence. In this David and Goliath situation, David is on a rack of death that has been slowly tightened over the ycars by a process we describe as "escalation." Goliath has had and continues to have the capacity at any point to kill David, but has sought instead to inflict pain and to threaten increas. ing pain until David gives in to the demands of Goliath. There is no reciprocity in such a situation of inequality. To claim restraint for Goliath is to ignore the rationale for this way of proceeding by stages. Among other factors to bear in mind is that Goliath knows that David has powerful, Goliath-like friends that may enter the sccne more actively. See, e.g., the report of Harry Ashmore's visit to Hanoi on behalf of the Center for the Study of Democratic Institutions in which he quotes "a Colonel of the North Vietnamese General Staff" who "answered very solemnly" a question about his estimate "of North Vietnam's capacity to resist the American troops":

We've thought about this a great deal. We think we can handle up to $2,000,000$ 
In this respect, the mode of Type I conflict (Korea) allows proportionate defense responses including unilateral action against the attacking state, ${ }^{22}$ whereas in a Type II or III conflict (Viet Nam), third-party military action is either prohibited altogether or its scope confined to the political entity wherein the struggle is going on. In either event, the tendency to escalate is curtailed. My categorization of international conflict is intended to guide decision-makers and observers toward a sense of what is reasonable in a particular situation. A strong element of national discretion remains. The limits on international violence are only quasi-objective restrictions upon sovereign prerogatives..3 There

Americans. This assumes that you do not increase your bombing bejond its present level. I think your combat troops will concede that we are masters of guerrilia war. We should be-we've been at it for twenty-fire years. We are far less dependent on heavy supplies than your army. TVe are accustomed to fighting in this terrain of jungle and mountains and this advantage offsets the undoubted superiority of your sophisticated weapons and planes. This is why we think we can handle up to 2,000,000 of your troops, and stay here the rest of the century if necessary. Of course, if you put in more than $2,000,000$ soldiers, or if you escalate the bombing to the point where you completely destroy our communications, then we have to accept volunteers from China, from Russia, and it would be a new war. It would no longer be our war. It would be World TWar III.

Mr. Ashmore commented that:

I have to assume an element of propaganda in this, but I also say that $I$ believe the Colonel meant what he said, and was consciously reflecting the considered judgment of the North Vietnamese government. Ashmore, Pacem in Terris II: Alission lo North Dietnam, Center Dlary, March-April 1967, at 17.

22. Korea is not truly an example of Type I, but of Type IV, because the United States' role was authorized by the United Nations; see pp. 1106.07 infra for explanation of Type IV. Nevertheless, to point up the relationship between Korea and Vict Nam it is possible to pierce the cosmopolitan veil, emphasize Sovict opposition and question the propriety of an authorization obtained in the Security Council during the Soviet boycott, and thereby view the response in Korea as if it proceeded without benefit of United Nations approval. In that case, Korea would appear to be an instance of Type I authorizing whatever military action is needed to restore the status guo ante the armed attad. On this basis I believe that the defensive armies should not have proceeded beyond the 38th Parallel, although it would have been permissible to commit war acts against North Korean territory so is to restore the status quo ante.

23. The Legal Adviser, Leonard Meeker, finds no diffeulty in reconciling my ategories of analysis with United States policy in Viet Nam: "The evidence does not allow for the conclusion that the war in Viet-Nam was erer a simple category-one situation. It was probably, for quite some period of time, a category-tro situation. By the end of 1964, however, it had become very clearly a category-uhree situation." Aiceler, "ict-Nam and the International Law of Self-Defense, 56 DEP'T STATE BuLL. 54, 59 (1967). Mr. Mreeker merely characterizes the facts to support the American legal position, including the shift of the war into "the third category." (Iype I) By the end of 1964, mainly orer a period of four years, about 40,000 are reported to have infiltrated from North Viet Nam according to official United States statistics. Mlost of those inflitrated during this period were ethnic Southerners that joined up with Vietcong units. There are several factors that militate against Mr. Meeker's inference of "armed attack" (that is, category three): first, the insurgency pre-existed North Vietnamese infiltration; as Fall notes "there had been a fairly strong anti-Diem insurgent current of non-Communist origins cven before the 1956 deadline on elections between the two zones went by. ..." B. FAL, TIIE Two VIETNaMs 356 (2d rev. ed. 1967) (cf. map showing pattern of insurgent control as of 1962.63, p. 354); second, the Saigon regime was enabled to resist the N.L.F. in the gears before 1961 only because it was given such large amounts of economic support by the United States in the years after 1954; as the first Mansfield Report obseries "in matters of 
is also some uncertainty as to whether a particular conflict belongs in one category rather than another. So long as the organized international community is unable to determine the limits on authorized violence, thereby placing the conflict within Type IV (see next paragraph) it remains necessary to rely upon national discretion. The objective of articulating Types I-III is to enable a more rational exercise of national discretion through the clarification of the relationship between factual patterns and legal expectations. If states would adhere in practice to these limits, ex parte interpretations of fact and of law on claims to use violence in international society would decline in importance.

Professor Moore's world order position, as presently stated, ignores the relevance of international institutions and of a supranational perspective to an assessment of the legal status of a controverted use of military power. To emphasize the problem of curtailing national discretion in a world of political conflict I would now add Type IV to the previous three types. ${ }^{24}$ Type IV conflict exists whenever a competent international organization of global (IVa) or regional (IVb) dimensions

defense, internal stability and economic support, the Vietnamese Government has come to depend almost wholly on the United States for outside assistance. In terms of aid, the assumption of this preponderant responsibility has meant U.S. outlays of $\$ 1.4$ billion for economic assistance during the period of 1955-62. This economic aid has had some effect on Vietnamese development, but its primary purpose has been to sustain the Vietnamese economy so that it, in turn, could maintain the burden of a military establishment which has been upward of 150,000 men for the past half decade. On top of the cconomic aid, there has also been provided large amounts of military equipment and supplies and train. ing for the Vietnamese Army, Navy, and Air Force and for other defense purposes, For the period 1955-62 the total of aid of all kinds in Viet Nam stands at more than $\$ 2$ billion. The MANSFIELd REPORT, app. II, at 19. For tables on the degree of United States involvement since 1954, see G. KaHIN \& J. Lewis, THE UNITEd STATes IN Vietnam 73, 185 (1967) [hereinafter cited as KAHIN \& LEwis].

The point is that North Vietnamese military assistance to an ongoing insurgency was a proportionate response at all stages to the extent of United States involvement on behalf of Saigon. And when one considers that North Viet Nam had a reasonable (if not absolutely assured) expectation that the Geneva settlement would lead to unification under their con. trol after a period of transition enabling the French to depart, then the American interposi. tion of a powerful non-Vietnamese "presence" must also enter into an appraisal of North Viet Nam's pre-1965 role. In such a context it seems unreasonable and without legal foundation to construe North Viet Nam's military assistance to the Vietcong as becoming an attack by one country on another. Without such a premise of attack, the United States response against North Vietnamese territory would be "unprovoked aggression." Recourse to self-defense implies a prior armed attack, and that is why United States position depends on "the armed attack" taking place before bombing the North began in February 1965.

24. In my earlier article, then, Korea and Suez are not properly examples of Type I after there was authorization of defensive action by the United Nations. Type I becomes Type IV as soon as the United Nations itself acts or authorizes action. The description, then, of Type I, in Falk, supra note 1, at 1126, should be amended accordingly. Types II and III can also be transferred into Type IV, although the conjectural nature of the facts and the less direct connection to international peace and security makes such a transfer less likely to take place. The Indian attack upon Goa and the Chinese attack upon Tibet are examples of Type I provided the victim entities are entitled to the status of "states." Goa's defensive prerogatives are also qualified by the limited legitimacy of colonial title to territory as of 1961 . 
authorizes the use of force. ${ }^{25}$ Type IVa can be illustrated by reference to United Nations actions in Korea (1950), Suez (1956), Cyprus, and the Congo (1960). The authorization or prohibition of violence by the United Nations resolves the issue of legality, even though a particular decision may be arbitrary or unjust in any given set of circumstances. ${ }^{20}$ The point here is that Type IV entails an authoritative consensus that may be absent in Types I-III. ${ }^{27}$ Thus, the context of my first Yale article

25. The legal status of Type IVb is more problematical than that of Type IVa. For one thing regional organizations are themselves subject to regulation by the Security Council (Article 53(1) says that "no enforcement action shall be talien under regional arrangements or by regional agencies without the authorization of the Security Council."). For another, the opposition of the Arab League to Israel, of the Organization of African Unity to South Africa, and of the Organization of American States to Castro's Cuba points to the danger of "aggression" under the legitimizing acgis of supranationalism. At the same time, the existence of regional support for recourse to coercion is a factor that alters the legal status of a controversial use of military power. It is important to dis. tinguish a regional actor-such as the O.A.S.-from an ex parte defensive alliance-such as SEATO. Authorization by SEATO would not move the conflict into Type IV'b, alturough the absence of such authorization might cast light on claims to respond within the framework of Type I.

26. This possibility leads Julius Stone, among others, to deny almost altozether the restrictive impact of the Charter system of controls upon the discretion of sovereign states. J. STONE, AGGRESSION AND WORID ORDER 1-3, 78-103 (1958).

27. In the absence of an authoritative consensus on a global level that cmbodies divergent perspectives, the construction of second-order constraints upon adversary perspectives is the essential task of international Iaw. Types I-III provide quasi-objective guidelines that tend to confine an international conflict. Departures from these guidelines could be justified legally by exceptional circumstances and for specific objectives. But the second-order system of constraint depends on a fair correlation of the conlict with the system of graduated categories. The United States insistence on vicwing North Viet Nam's role as warranting a Type I response is destructive of second-order constraints as the basic categorization does not command respect from many uncommitted observers. The generalized bombing of North Viet Nam could not be easily justified as an exception to Type II. Specific attacks upon extra-territorial guerrilla sanctuaries might be justified if the conflict was otherwise contained within Type II limits. But the objectives of bombing North Viet Nam seem primarily connected with an overail effort to secure their acquiescence to our conception of the war in South Viet Nam. President Jolunson's letter of March 1, 1967 to Senator Jackson gives the Government's rationale for bombing North Viet Nam in fairly complete terms; significantly, this letter ends by saying "we shall persist with our operations in the North-until those who launched this agsression are prepared to move seriously to reinstall the agreements whose violations have brought the scourge of war to Southeast Asia." Earlier the letter says that bombing will end when the other side is willing to take equivalent action. " (emphasis added). See President Reviews US. Position on Bombing of North Piet-Nam, 56 DEP'T STATE BuL. 514, 516 (1967). What is equivalent action if it is conceded that extra-territorial violence is, at best, an extraordinary incident of a Type II conflict? Supplying and sending troops to aid the N.L.F. is a normal incident of Type II conflict. To demand, as secms implied by the official United States position, the elimination of a normal claim by a third-party state in exchange for the termination of an extraordinary claim (and in Viet Nam the extraordinary nature of the claim is aggravated by its assertion in extravgant, unspecific, and accelerating form) by its third-party opponent seems highly unreasonable. It is worth recalling that the United States original justification for bombing North Vict Nam in February 1965 was formulated in the restrictive and exception-cxplaining logic of Tspe II as a reprisal for Vietcong attacks on United States airfields in South Viet Nam; it is worth noting that the legal reflex in February 1965 was in the manner of Type II, not Type I. This is worth noting because of the subsequent official explanations that the Viet Nam war clearly belonged to Type I by the end of 1964. Cf. note 23 supra; sec also The Legality of United States Participation in the Defense of Vict-Nam, Office of the 
and of this reply to Moore is provided by the conflict in Viet Nam, a conflict in which the United Nations has not been able to act collectively through its main political organs. ${ }^{28}$ This context is in the range of Types I-III. ${ }^{20}$

Having set forth the factors that shape my world order position, I will turn now to Professor Moore's specific criticisms of my approach. He has three main objectives:

(1) I have construed the Viet Nam facts in a one-sided manner;

(2) My system of categorization imposes arbitrary limits on a state using force for defensive purposes;

(3) My system really declares my views as to what international law ought to be although it pretends to be a statement of present legal obligations binding upon a state.

Professor Moore's first principal criticism pertains primarily to my argument that it would have been appropriate to regard the conflict in Viet Nam as an example of a Type III conflict, that is, as an example of civil strife internal to one country. The second and third criticisms pertain primarily to my chief argument that the conflict in Viet Nam, whatever its early history, has become an example of Type II conflict, that is, an example of civil strife in South Viet Nam with substantial intervention on behalf of the two contending factions, the Saigon regime and the National Liberation Front (N.L.F.) (these criticisms are discussed below in Section II).

Legal Adviser, Department of State, 112 Conc. REc. 5274 (daily ed. March 10, 1966), For original reliance on a reprisal theory see Falk, supra note 1, at 1145; for legal criticism of even the attempt to rely on a reprisal theory see Consultative Council 53.57.

28. But the United States bears a heavy burden of responsibility for the inaction of the United Nations as a consequence of the following considerations:

(1) Non-compliance with the proposals of the Secretary General, U Thant;

(2) Non-submission of the claim to act in self-defense to the Security Council

or General Assembly for serious community review;

(3) Refusal in early stages of conflict to seek a peaceful settlement through negotiations;

(4) Alienation of China from the United Nations by its continuing exclusion from the activities of the Organization;

(5) Ambiguity as to the sincerity of United States offers to negotiate, as a con. sequence of coupling peace moves with steps up the escalation ladder. For scholarly documentation see F. SchurmanN, P. ScotT, \& R. ZELNIK, THE Poutros of Escalation IN VIETNAM (1966).

29. The important distinction is between the sort of legal ordex that exists for Types I-III and for Type IV:

Types I-III are governed by second-order constraints self-imposed by sovereign states and hased upon such quasi-objective sources of guidance and limitations as past practice, public opinion, recommendation of impartial third-party actors such as the Secretary General and the Pope, and well-defined international boundaries.

Type IV conflicts are governed by first-order constraints consisting of the determinations of international institutions. First-order constraints are procedural out-comes on a supranational level, whereas second-order constraints are substantive out-comes on a
national level. 


\section{The Rationale Restated in Support of a Type III Classification of the Viet Nam War}

Let me state clearly that when large-scale military participation by the United States in the war began to take place-say 1963-it became appropriate to treat the conflict as Type II. North Vietnamese largescale military participation on behalf of the N.L.F. accentuates this classification of the war. My principal contention denies that the factual basis exists to warrant treating the Viet Nam War as belonging in Type I (which would authorize extra-territorial defensive measures) and, as a correlate denies that there exists a legal basis for extra-territorial violence if the war is classified as Type II. However, it remains important to consider the conflict in Viet Nam also as belonging originally in Type III so as to appreciate the principal role of the United States in converting the war into Type II, such a conversion involving conduct itself seriously at variance with my conception of the requirements of world order. ${ }^{30} \mathrm{It}$ is also important to acknowledge that the

30. The transformation from Type III to Type II is a matter of policy rather than law in any normal sense; "In sum, international law has never been equipped to intervene in civil war situations." Friedmann, Intervention, Civil War and the Role of International Law, 1965 Proc. ANr. Soc'y INT'L L. 67, 74. There are no criteria that are uscfully available to identify prohibited interventions, although some efforts have been recently made to prohibit overt and direct military participation. See Farer, Intercention in Civil Wars: $A$ Modest Proposal, 67 ColvM. L. REv. 266 (1967). The real issues of policy confronting the United States are the degree to which it reacts to revolutionary crents in the AfroAsian and Latin American countries as properly hostile to its interests. For critical accounts of this aspect of foreign policy, see E. Stuliaran \& W. PFAFF, Power ANd IMrotesce, 15-59, $184-226$ (1966); H. ZINN, VIETNAM: THE LoGIC OF WIMIDRAwal 37-50 (1967); and see T. HANe, VIETNAM LOTUS IN A SEA OF FIRE 60.6S (1967) for the entangling of nationalism and communism in the Viet Nam setting. For a pro-Administration judgment of the American response to foreign revolutionary activity see W. Rostow, The Great Transition: Tasks of the First and Second Postuar Generations, 56 DEp'T STATE BuLt. 491 (1967).

The transformation from Type $I I$ to Type $I$ is regulated by international law as it implies violent conflict between sovereign states rather than within a sovereign state. Initiating recourse to international violence, as distinct from interientionary violence, requires the prior occurrence of an armed attack.

The consequences of this difference between shifting from III to II and from III or II to I are to make different kinds of legal arguments appropriate in each context. At the same time the difference in argument can be over-stated. A successful claim by a state to act in a manner not previously regarded as legal may itelf constitute authoritative state practice that can be relied upon in the future by others, thereby transforming what had once been regarded as prohibited into what comes to be regarded as permirsible. In a context where legal expectations have been regarded as well-fixed polic;, considerations may incline an actor to posit a legislative claim, which if effectivcly asseried and accepted by the wider community, tends to reshape legal expectations. In both contexts, thereforc, there is an unavoidable discretionary role plajed by the state with the capability to act in different ways, but in the interventionary axis of decision (III-II) there is less disposition to regard the decision to intervene as a weakening of legal order than in the armed attack-self-defense axis of decision wherein legal expectation of fairly setued character had been thought to exist, especially in view of the coordinated United States-Soviet opposition to the French-British-Israeli recourse to overt violence in the Sucz Campaign of 1956. 
expectations of North Viet Nam and of the N.L.F. were likely formed prior to the overt, large-scale intervention by the United States-that is, when the conflict still belonged in the Type III category. Clarifying the factual and legal reasons for regarding the early stages of the war as Type III is very centrally related, in my view, to the North Vietnamese perception of what would constitute a reasonable outcome of the Viet Nam war (regardless of its subsequent Type II history).

In considering the war in Viet Nam as belonging in Type III, especially in its early (pre-1963) phases, I intended a two-pronged argument: first a civil war between the two factions in the South and second, a civil war between the Northern and Southern Zones. My argument was essentially that in either case such a conflict should be determined by the domestic balance of forces and, that, in the setting of Viet Nam under either interpretation the anti-Saigon "entity" would have prevailed but for American (that is, non-Vietnamese) military intervention. My reasoning is essentially as follows: South Viet Nam had evolved, despite the contrary intentions of the Geneva Settlement, as a separate de facto political entity, and the N.L.F. emerged as a sufficiently indigenous opposition movement to be deemed South Vietnamese in character rather than as an "agent" or "puppet" of North Viet Nam. ${ }^{31}$ In this circumstance the outcome of the N.L.F.Saigon struggle would have been an N.L.F. victory if both the United States and North Viet Nam had remained out of the conflict, and the quantum and phasing of United States and North Vietnamese aid to the contending factions was imbalanced in favor of Saigon at every stage subsequent to 1954. This interpretation of the early stages of the Vietnamese conflict seems to enjoy the support of almost all disinterested analysts. ${ }^{32}$

The second prong of the Type III analysis conceives of the war in

31. To take seriously the issue of the autonomy of the N.L.F. it would be necessary to compare its dependence on Hanoi with Saigon's dependence on Washington at the various phases of the war. Cf. J. LACOUTURE, VIETNAM: BETwEen Two TRucrs 61-119 (1966) [hereinafter cited as LACOUTURE]; KAHUN \& LEwIs, esp. chapter entitled "Americanization of the War," at 151-80. The autonomy of Saigon's discretion to terminate the war on its own terms, as distinct from those insisted upon by Washington, is certainly as doubtful as is the autonomy of the N.L.F. to terminate the war on conditions at variance with those insisted upon by Hanoi.

As to the extent of the American role at earlier preinsurgency stages of South Vict Nam's history see E. HAMmer, The Struggle For Indo-ChINA 1940-1955 346.64 (1954.55); "However much American officials may have wished to regard southern Viet Nam as independent, the fact and the promise of substantial American aid to the Nationalist regime gave them such influence that in the fall of 1954 it was the United States, not the Vietnamese people, who decided that Ngo Dinh Diem would continue to be Prime Minister of southern Viet Nam." Id. 356.

32. Lacouture 186-90; KaHIN \& Leivis 127-206; The MaNsfield Report 11-12. 
Viet Nam as a civil war between South Viet Nam and North Viet Nam waged for control of the state of Viet Nam. According to Professor Moore, such a characterization of the war overlooks the separateness as of 1960 of these two political entities, as well as the essential ambiguity of the Geneva settlement, especially with regard to reunification. Professor Moore, although sensitive to the particularities of the division of Viet Nam in 1954, closely associates the status of Viet Nam with such other divided countries as Korea, Germany, and China. Force across a partition boundary is, as he properly points out, dangerous to world peace since the de facto divisions express major unresolved conflicts between the Communist and non-Communist worlds. I challenge Professor Moore's analysis on two principal grounds:

(1) The division in Viet Nam is not usefully comparable on policy grounds to that of other divided countries;

(2) The defeat of the French by the Viet Minh as embodied in the Geneva Settlement of 1954, the attitude of Saigon toward the Geneva Accords, the Southern locus of the uprising, the small magnitude of Northern interference as compared to the direct and indirect military contributions of the United States Government to Saigon, the nonviability of the regime in the South, and the national popularity of Ho Chi Minh are factors that when taken into joint account make it misleading to talk of "the aggression" of the North.

\section{The Geneva Settlement: Face-Saving or Partition}

Sir Anthony Eden, introducing his discussion of the Geneva Accords of 1954 and his ideas for settling the present war in Viet Nam, has said that

No agreement can be so drawn as to be proof against every malevolent intention. That is why the observance of international engagements is the first condition of any peaceful society. Once allow treaties to be torn up with impunity and the rworld is headed for trouble; violators soon have imitators. ${ }^{33}$

It seems to me that Professor Moore is somewhat cavalier in explaining away the United States' insistence on non-implementation of the election provision in the Final Declaration by setting it off against a Western preference for "partition" that was consistently denied both by the language of the Agreement on the Cessation of Hostilities in Viet Nam and of the Final Declaration. ${ }^{34}$

33. A. Eden, Toward Peace in Indochina 31 (1966).

34. See especially Articles 1-9, 11-15, and 27 of Agreement on the Cessation of Hostilities 
Ignoring the relevance of formal international engagements Professor Moore also supports the double standard whereby North Viet Nam's alleged export of coercion through the N.L.F. is viewed as a material breach of the Geneva Accords, whereas the United States' pro. vision of military aid to Saigon, even though it admittedly preceded North Vietnamese coercion, is approved of as a "permitted defensive response." Moore facilely circumvents the determination by the International Control Commission that both sides were guilty of violations of the Geneva Accords which were not weighted as to relative seriousness, by asserting that "this neutral reporting proves little." 35 In fact, for Professor Moore the determination of the I.C.C. proves less than does the unsupported balancing of these two violations by an interested party-namely, the United States Government. As elsewhere in his analysis Professor Moore seems to endorse the discretionary competence of sovereign states at the expense either of binding international arrangements or of the determinations of impartial machinery set up to implement these arrangements. If the United States was so convinced that its aid to Saigon was a permissible defensive response then why did it not have this conclusion confirmed by the I.C.C. or by a reconvened Geneva Conference in the course of the years since 1954? There is little doubt that from the time when the meetings were going on in Geneva in 1954 the United States was determined to use its unilateral military power to avoid the translation of the Viet Minh's military victory over the French in the First Indochina War into a corresponding political victory. Once again it is worth quoting Anthony Eden, partly because he was a principal participant at Geneva and partly because his Tory credentials are so impeccable:

[Dulles] reiterated his fears that, in the event, France would be compelled to depart from the seven points, and the United States would then have to disassociate herself from the resulting agreement. He said that even if the settlement adhered to the seven points faithfully, the United States still could not guarantee it. ${ }^{30}$

I had already been warned by Bedell Smith that the United States Government could not associate themselves with the final declara-

in Viet-Nam, July 20, 1954 and Articles 6 and 7 of the Final Declaration of Geneva Conference, July 21, 1954, SENATE Foreign RELATIONs ComM., 89th Cong. 1st Sess., BAckcround INFORMATION RELATING to SOUTHEAST AsIA AND VietNaM, 28.42, 58.60 (rev. ed. June 16, 1965) [hereinafter cited as BACKGROUND INFORMATION.]

35. For example, paragraph 84 of the Sixth Interim Report of the ICC, December 11, 1955-July 10, 1956 reads as follows: "While the Commission has experienced difficulties in North Vietnam, the major part of its difficulties has arisen in South Vietnam." 83 PARL. Sessional Papers, CMD. No. 31, at 30 (1956-57).

36. A. Eden, Full Circle 156 (1960). 
tion. The most they could do was to issue a declaration taking note of what had been decided and undertaking not to disturb the settlement. Since Dulles had been at least as responsible as ourselves for calling the Geneva Conference, this did not seem to me reasonable. $^{37}$

There are two points to note. First, the United States' determination from the outset not to be fully associated with the Geneva Settlement. Why is this so if Professor Moore's view of its essential understanding is correct? To answer this by saying that the United States wanted to avoid ratifying the Communist acquisition of North Viet Nam is hardly a sufficient explanation (even if it is a part of the story) in light of Dulles' overall insistence upon preserving a free hand for American action in the future. The second point, one that strikes me as legally pertinent, is why it matters whether the United States approved of the Geneva Accords or not. The parties to the conflict had full power to settle it by agreement. It is rather far-fetched to contend that the United States assent is needed to secure a formally binding arrangement reached to end a war in which the United States was not itself a direct participant.

Not everything complex is ambiguous. Professor Moore's argument that the Geneva Settlement was ambiguous on the issue of unification is unconvincing on several grounds:

(1) The election provisions of the Geneva Accords are explicit as to date, auspices, and preconditions; ${ }^{38}$

(2) The fact that the Geneva Declaration was unsigned does not seriously detract from its character as a binding legal instrument; ${ }^{33}$

37. Id. 159-60.

38. Falk, supra note 1 , at 1129 (and authorities cited in note 31, supra); CoNsultatnve COUNCIT 43-48; KAHIN \& LewIS 52-55, 80-87; 2 BUTTINGER 839-10; the most detailed support for regarding the failure to hold the elections promised by Article 7 of the Final Declaration for July 1956 as frustrating Hanoi's sincere understanding of the Geneva Settlement is contained in a well-researched monograph, Wcinstcin, Victnam's Unheld Elections (1966) (Data Paper No. 60, Southeast Asia Program, Cornell Univ.); cf. Lacouture, The "Face" of the Diet Cong, War/Peace Report, May, 1966, at 7, 8: "One cannot say" .. . that the North resigned itself, with only pro forma protestations, to Dicm's refusal to hold the elections that had been legally set for July, 1956. During his trip to New Delhi in 1955 as well as in three separate attempts at the end of 1955 and at the beginning of 1956, Pham Van Dong, the present premier of North Vietnam, attempted to implement the provisions of the Geneva agreement. He even offered to delay the elections on condition that Saigon pledge to allow them. It was the great powers-the U.S.S.R. and Peling included-who forgot the Geneva recommendations, not Hanoi, which found itself for the second time "cheated'." For a full account of the first time Hanoi was "chented" sce HAMMLR, supra note 31, at 148-202; a briefer account is contained in KaruN \& LEwis 25.28.

39. See Kakm \& Lewis 51 (and citations contained in note 7 therein), including reference to Article 3(b) and commentary thereto as contained in U.N. Doc. A/16309 (1960). The fact that the United States withheld its oral assent from the Final Declaration and attached a Declaration somewhat at variance with Article 7 does not alter the legal 
(3) The refusal of the Saigon regime to accept the Geneva Accords does not relieve it of the obligation to comply as France had the capacity that it explicitly sought to exercise, to bind its "successor";40

(4) Experienced and impartial observers generally agree that (a) unification by means of elections was part of the Geneva Settlement and (b) elections, if held, would have resulted in the consolidation of Viet Nam under the control of Hanoi; ${ }^{41}$

(5) The United States was from the beginning manifestly discontented with the Geneva solution, refused to endorse the outcome as a party, and set about almost immediately thereafter to undo the fulfillment of its terms. ${ }^{42}$

Moore advises analysts to consider the total context of Geneva and yet he neglects these critical factors. He is correct in pointing to a certain aura of ambiguity connected with securing the compliance of Saigon with a settlement that was expected to extinguish its sphere of influence. It is also appropriate, as Moore suggests, to acknowledge the subsequent de facto sovereignty of both North and South Viet Nam, regardless of the intentions at Geneva in $1954 .{ }^{43}$

expectations created among the real parties in interest-the French and the Viet Minh. For text of the United States Declaration, see BACkGRound INFormarion, 61: "In conncc" tion with the statement in the declaration concerning free elections in Viet-Nam my Government wishes to make clear its position which it has expressed in a declaration made in Washington on June 29, 1954, as follows:

In the case of nations now divided against their will, we shall continue to scek to achieve unity through free elections supervised by the United Nations to insure that they are conducted fairly.

With respect to the statement made by the representative of the State of Vict-Nam [Bao Dai], the United States reiterates its traditional position that peoples are cntitled to determine their own future and that it will not join in an arrangement which would hinder this. Nothing in its declaration just made is intended to or does indicate any departure from its traditional position."

It is obvious that the United States alters the terms of Axticle 7 by the conspicuous omission of a definite date upon which elections should be held in Viet Nam and by the call for United Nations supervision. It is also clear that the refusal to give oral assent to the Final Declaration and the reference in the United States Statement to its refusal "to join in an arrangement" which "would hinder" its election policy indicates the serious intention of the other participants to take seriously the terms of Article 7. It is one thing for the United States and the Bao Dai regime to disassociate themselves from the Final Declaration, it is quite another to contend that the enforceability and centrality of the election provision was in any respect reduced thexeby.

40. This conclusion appears to be persuasively established in Partan, Legal Aspects of the Vietnam Conflict, 46 B.U.I. REv. 281, 289-92 (1966).

41. See the authorities cited at note 38 supra for relevant references, especially Wein. stein. A typical comment is in B. FALL, THE Two VIEr-NAMS (2d rev. ed. 1967), at 231, who writes that "On the grounds of its nonsignature, South Viet-Nam refused to hold elections by July 1956, since this would have meant handing over control of the South to Ho Chi Minh."

42. Cf. B. Fali The Two VIET-NaMs $229-33$ (2d rev. ed. 1967); KAHIN \& LEwis 57.63; 2 ButTINGER 834-42.

43. The expectations created as of 1954 remain relevant to the perception by North Viet Nam of what constitutes a reasonable outcome of the Second Indochina War, and influences the formulation of minimum negotiating demands. 
It would consume too much space to refute Moore's interpretation of the Geneva Accords on a point-to-point basis especially as this task has already been done effectively by other authors." I would, however, suggest the weakness of Moore's position by reference to the long passage he approvingly quotes from a book by Victor Bator. In this passage Bator argues that the Geneva Accords really intended "partition" and that this position is borne out by "the detailed accounts of Bernard B. Fall, Jean Lacouture, and Philippe Devillers." 10 Here is what Devillers actually thought about the Geneva Settlement:

The demarcation line was to be purely provisional; the principle of Vietnamese unity was not questioned, and the idea of partition was officially rejected with indignation by both sides. ...

The disproportion between the monolithic power of the Vietminh, armed and with the halo of victory, and the almost derisory weakness of the so-called Nationalist Viet Nam was such that in the summer of 1954 almost no one thought that the two years' delay won by $M$. Mendes-France at Geneva could be anything but a respite in which to salvage as much as possible from the wreck. At the end of the period, unity would certainly be restored, this time to the benefit of the Vietminh, the basic hypothesis then acknowledged by all being that the Geneva Agreements would definitely be implemented (emphasis supplied). ${ }^{\text {to }}$

Devillers' position has recently been reaffirmed by Professors Kahin and Lewis in their careful and fully documented account of the Geneva Conference. These authors describe Geneva as the event that "officially registered France's defeat by the Vietminh and provided her with a face-saving means of disengagement." ${ }^{137}$ In this regard Kahin and Lewis aver that it was the "promise of elections that constituted an essential condition insisted upon by the Vietminh at Geneva." Their reasoning is well worth quoting:

44. See KaHin \& Lewis 43-65; also relevant on many points is D. Lasicaster, TuE EMIANCIPATION OF FRENCH INDOCHINA 313-58 (1961).

45. In a long and significant scholarly review article, itself not hostile to the United States' role in Viet Nam, John T. McAlister says of Bator's longer interpretation of the Geneva Conference in V. BAToR, VIET NaMr: A Diplosatic Traced (1965) that it "is an emotional and polemical book making no claims to be a scholarly work." MIcAlister, The Possibilities for Diplomacy in Southeast Asia 19 WorLd PoLrics 258, 269 (1967); Bator's article from The Reporter has been reprinted along with a series of other strongly proAdministration articles drawn from the magazine and reflecting its partican editorial slant in Viet Nam-Vietnam: Why-A Collection of Reports and Cosmers fross The REPORTER (1966). It is, hence, strange to rely upon an occasional picce by Bator, vere it not the case that the more trustworthy commentators in the Geneva Conference all cast doubt upon "the partition" hypothesis.

46. Devillers, The Struggle for Unification of Vietnam, TuE Cuna Quartersy, Jan.March 1962, 2-3.

47. KaHiN \& Lewis 43. 
France was prepared to pay the political price of that condition in order to get the armistice that she so urgently wanted. Her successor [in Saigon] would be obliged to abide by that condition or face the certain resumption of hostilities. The reason for this is patent: when a military struggle for power ends on the agreed condition that the competition will be transferred to the political plane, the side that violates the agreed condition cannot legitimately expect that the military struggle will not be resumed.8

Professor Moore relies upon the memoirs of Anthony Eden to estab. lish "that the real core of the settlement, at least from a Western standpoint, was partition of Viet Nam. . .." (1059) These memoirs are too imprecise to clarify legal analysis and are internally inconsistent, ${ }^{40}$ although they do provide considerable insight into the divergence of the American position from that of the other Western powers at Geneva in 1954. Eden, who holds very intense anti-Communist views, is especially convincing in his account of the effort that he made to discourage the United States from undermining the whole project of a conference to end the first Indochina war.50 The United States was lobbying at Geneva in support of a collective Western intervention in support of the French, support that the French no longer desired. Eden indicates that he was distressed to learn from a French diplomat about an official document in which the United States secretly proposed to the French that military intervention in Indochina occur "either after the failure of Geneva, or earlier if the French so desired, and he emphasized that the American preference had been clearly expressed for the earlier date" (emphasis supplied). ${ }^{51}$ It seems to me that a fair-

48. Id. 57 .

49. Anthony Eden seems primarily concerned with obtaining a Western negotiating consensus that would enable the war in Indochina to be brought to an end. There is no detailed interpretation given by the terms of the Geneva settlement and there is cvery indication that Eden thought that the election provisions would be carried out, despite the intra-Allied discussion in terms of "partition." A. EDEN, Ful. Circle 158.59 (1960). It is very strange to argue that the negotiating hopes of the United States, which werc not to any degree reflected in the language or terms of the Accords themselves, should be given any weight in construing treaty-type obligations that are unambiguous on their face. It is an elementary rule of treaty interpretation that one consults the context of the agreement only to the extent that the provisions themselves are unclear. Even if the Accords do not qualify as treaties in the strict sense their content was affirmed in a solemn and formal manner. In any event, although the rhetoric of partition docs imply a permament separation of Viet Nam into two separate states, it is quitc con. sistent with a temporary period of partition followed by elections sceking reunification. Only such an interpretation brings consistency into the Eden accounting. For the most persuasive skeptical view of the Geneva Accords-one that puts a curse on both houscssee 2 BuTTINGER 978-81.

50. A. Eden, Full Circle 120-63 (1960).

51. Id. 134; cf. id. 93, 103, 117, 126-27 (for a sense of Eden's perception of American attitudes toward the Geneva Conference). Buttinger's account of the American attempts to rally support for military intervention is one of the most complete and 
minded reading of the Eden memoirs would emphasize the degree to which talk of "partition" may have been designed to mollify the United States apprehensions about the Conference. In any event, if "partition" was the bargain, it was nowhere reflected in the Geneva Accords that resulted from the Conference. Why not?

The partition hypothesis also does not reconcile easily with Eden's evident feeling that the election provision in the Final Declaration was to be taken seriously:

The Communists insisted that elections should be held during 1955 in Vietnam, whereas the French maintained, I thought rightly, that it would take at least two years for the country to be restored to a condition in which elections would be possible."

I conclude that ( $\mathrm{I}$ ) partition was not written into the Geneva Accords and that (2) unification by elections in July, 1956 was the essential political bargain struck at Geneva in exchange for a regroupment of the fighting forces into two zones and the withdrawal to the North of the Vietminh armies. This interpretation of the Geneva Accords is crucial for an interpretation of the relevance of the post-1954 events, especially of the extent to which one emphasizes or disregards the nonimplementation of the election provision. My principal contention is that once it became clear that the election provision would not be carried out recourse to coercion by Hanoi was both predictable and permissible in either of the two Type III variants-the N.L.F. versus Saigon or North Viet Nam versus South Viet Nam. On this basis I find it highly misleading and false to analogize the evidence of North Vietnamese support for the insurgency in the South with the massive attack by North Korea on South Korea in 1950. It is false even if (which is hardly possible) one accepts the State Department's "white papers" as accurate descriptions of the North Vietnamese role in the early stage of the conflict in South Viet Nam. Among other considerations distinguishing Korea are the following: the effort of Hanoi proceeded against a quite opposite political background, it was based on much more ambiguous evidence of coercion, and the coercion was of a such small scale that it could not have resulted in any substantial disturbance had not a revolutionary potential preexisted in South Viet Nam. ${ }^{53}$

accurate, 2 BuTrINcer 797-844; he writes that "the mores that Radford, Dulles, and Nixon made during April 1954, to stop Communism in Indochina are among the saddest chapters of U.S. diplomacy." Id. 819.

52. Id. 158, 159; see also A. EDEN, TowaRd PEACE IN INDochiNa 38 (1960).

53. E.g., Feldman, Violence and Volatility: The Lilsclihood of Revolution, in $\mathrm{H}$. EcksteIN, ed., INTERNAL WAR 111-29 (1964). 
Viet Nam cannot be regarded as relevantly similar to the other divided countries of China, ${ }^{54}$ Korea, or Germany. Although Korea and Germany differ significantly from one another as divided countries, the political "settlement" in each case consisted of a reciprocal acceptance of partition, at least until a more satisfactory political settlement could be agreed upon as to reunification. Until such a second or new political settlement emerges, if ever, the use of coercion in any form to achieve a favorable military settlement of the reunification issue is, as Professor Moore properly indicates, a dangerous disturbance of world order, a disturbance that entitles the victim entity to claim full defensive rights and one that entails the gravest consequences; the Korean War illustrates and vindicates the principle that frontiers within divided states enjoy at least the same sanctity as frontiers between undivided states. The Saigon regime cannot invoke the sanctity of the seventeenth parallel in the same persuasive manner as the Seoul regime invoked the sanctity of the thirty-eighth parallel. The political settlement at $\mathrm{Ge}$ neva in 1954 provided a formula for the nullification (rather than one for the maintenance) of the division. In Viet Nam Saigon's establishment, rather than the subsequent attempt at its removal, of a political frontier at the seventeenth parallel represented the coercive challenge to world order. ${ }^{55}$

In this spirit it is worth reexamining Professor Moore's central policy test in the Viet Nam setting-namely, the prohibition by international law of coercion as a strategy of major change. On one level such a policy is an essential ingredient of minimum world order in the nuclear age. But peace cannot be divorced from minimum expectations of fair play on related matters. The Geneva Conference confirmed the results of a long anti-colonial war won at great cost to Vietnamese society by the armies of Ho Chi Minh. ${ }^{56}$ The achievement of national independence is a goal of such importance in the Afro-Asian world that it clearly takes precedence for these countries over generalized prohibi-

54. It can be persuasively argued, I think, that Formosa is wrongly conccived of as an integral part of China. Therefore, China is not "a divided country" at all, but there are two countries each of which is entitled to sovereign status. For a complete argument to this effect see L. Chen \& H. Lassweld, Formosa, China, AND tite UNited Nations: ForMosA's PLACE IN THE WORTD COMMUNITY (to be published in 1967).

55. See B. FALL, The Two VIET-NAMs 231-32 (2d rev. ed. 1967); the effort to build-up the military strength of the Saigon regime was coupled with its refusal to allow thic election provision of the Geneva settlement to be carried out. To defend the seventeenth parallel as if it were an international boundary was itself tantamount to an illegal effort at splitting a state into two parts, an effort frequently productive of severe civil strife. It is only necessary to recall the American Civil War or the post.1960 efforts of Katanga to split off from the Congo.

56. See HAMMER, supra note 31 . 
tions on force or rules about non-intervention. ${ }^{57}$ The Geneva Accords are not just an international agreement about which a dispute arose, but a formalized acknowledgment of a political outcome that it is reasonable to suppose could have been attained legitimately by the Vietminh in 1954 through military means. ${ }^{58}$ In effect, the Accords were a political bargain struck by the French as an alternative to continuing the appalling destruction of lives and property. To cast aside this political bargain is to undermine severely the security of solemn international agreements and to put in jeopardy collective procedures for pacific settlement. ${ }^{59}$

My conclusion, then, is that Professor Moore has not persuasively demonstrated that the use of coercion across the seventeenth parallel by North Viet Nam should have been regarded as coercion across an international boundary. I wish to argue only that it was reasonable for Hanoi, given the stakes and outcome of the first Indochina war, to regard Saigon's intransigence on the issue of elections as a material breach of the Accords allowing it to act on the basis of the status quo ante 1954: in my terms choosing this option would result in an example of Type III conflict, a situation of internal conflict for control of all of Viet Nam in which outside participation on behalf of either faction is "intervention," at least in the sense of interfering with the process of self-determination. ${ }^{60}$

Despite its plausibility from the perspective of law, there are three problems with this interpretation:

(1) Hanoi has not really contended that the action of Saigon nullifies the Geneva Accords; on the contrary, Hanoi continues to urge implementation and compliance;

57. For example, the African states overtly prodnim their intention to resort to force against the countries of Southern Africa to end colonialism and racism. The legal status of this claim is considered in Falk, The New States and International Order, 118 RecueIL DES Cours (1966).

58. After Den Bien Phu the only way to prevent a total Victminh victory would have been a massive United States military intervention, that included combat troops; as it was, even Anthony Eden points out that the French were the recipients of at least nine times as much foreign support from the United States as the Vietminh received from China. A. EDEN, FuLl CIRCIE 126-27 (1960).

59. The refusal of the United States to take the Genera Accords of 1954 more seriously as the terms of settlement may help partly to account for the reluctance of Hanoi to negotiate with the United States. Of course, there are independent reasons to suppose that the United States may not be sincere about its various offers to negotiate an end to the Viet Nam war. See Draper, Vietnam: How Not to Negotiate, New Yonk REvew OF Books, May 4, 1967, at 17; Draper's criticism of the Government is so impressive because of his earlier support of the United States' anti-Castro foreign polic;. T. Drapen, Castroisar Theorx aNd Practice (1965). Cf. KaHiN \& Lewis 207-37.

60. Quincy Wright has been a consistent adrocate of this position. See Wright, Legal Aspects of the Viet-Nam Situation, 60 Axr. J. INT'L L. 750 (1965); Wright, United States Intervention in the Lebanon, 53 AA. J. INT'L L. 112 (1959). 
(2) South Viet Nam has existed as a separate political entity for more than twelve years and has been accorded diplomatic recognition by many foreign governments; the consequence is a condition of statehood with all of the normal defensive prerogatives;

(3) During the last five years third-powers have become increasingly involved on both sides in the Viet Nam War; South Korea, Thailand, Australia, New Zealand, the Philippines, the Soviet Union, and China are the principal third-party participants as of April, 1967.

As I have indicated at the outset of this section the war in Viet Nam now belongs in Type II; the functions of clarifying the argument that it was originally an example of Type III and that the United States should have left it that way are to indicate the reasonable basis of a settlement and to emphasize the unilateral role of the United States in shifting the war to an internationally more serious category of conflict. ${ }^{61}$

II. The Rationale Restated in Support of a Type II Classification of the Viet Nam War

To classify the Viet Nam war as a Type II conflict implies considering the war as a variety of civil strife in which two domestic factions, each of which receives substantial assistance from foreign states, are struggling for control of a sovereign state. I maintain that international law then requires that belligerent conduct remain within the territorial limits of South Viet Nam. The United States Government officially repudiates this interpretation of the war and insists that the violent conflict is properly viewed as "an armed attack" by North Viet Nam upon South Viet Nam. South Viet Nam is thus entitled to act in selfdefense, including, to the extent necessary, the commission of acts of war in North Viet Nam. In my terms, the United States Government has inappropriately characterized "the facts" as vindicating a Type I classification. ${ }^{62}$

61. As a conflict moves from Type III toward Type II it tends to become more dangerous to international peace and security; as it proceeds from Type II to Type I it tends to become even more dangerous other things being equal. Therefore, the United States' role in transforming the conflict from Type III to Type I without scriously attempting at a Type IV classification is to follow a path destructive of world order in relation to the civil strife-revolution phenomena occurring throughout the Afro-Asian world.

62. The objective of establishing two categories of internationl conflict, Typa I and Type II, is to underline the importance in policy and in law to distinguish between the Korea-type situation and the Viet Nam-type situation. Analytic categories are idcal types; there is no comparable clarity in real-world situations. Nevertheless, the ambl- 
Professor Moore agrees with the Government that the war in Viet Nam belongs in Type I, but he goes further by arguing that even if the facts warrant a Type II classification there are no legal restrictions that necessarily confine the war to territorial boundaries and that, in the context of Viet Nam, the air and sea strikes against North Vietnamese territory have been legally reasonable. There are thus two broad sets of questions to which Professor Moore and I give different answers:

(1) Is North Viet Nam "intervening" in "civil strife" going on in South Viet Nam or is North Viet Nam "attacking" South Viet Nam? Who decides, by what criteria, and subject to what conditions?

(2) If North Viet Nam is regarded as merely "intervening" in civil strife, does international law prohibit South Viet Nam and states allied with her from committing war acts against the territory of North Viet Nam?

As Professor Moore effectively argues, South Viet Nam's de facto sovereignty makes it important to analyze the legal rights of the Saigon regime on the assumption that South Viet Nam is a sovereign state, as entitled as any other to act in self-defense and to receive military assistance. Moore's interpretation of North Viet Nam's role depends on two sets of assertions; neither of which I accept as to fact or law:

(1) The nature of North Viet Nam's military assistance to the N.L.F. and the political objectives motivating it constitute "an armed attack" upon South Viet Nam;

(2) The United States assistance to the Saigon regime, including bombing North Viet Nam, is a reasonable and lawful exercise of the right of self-defense.

My argument as formulated in the first article is that the conflict in South Viet Nam closely resembles other instances of prolonged civil strife in which substantial intervention by foreign countries on behalf of both the insurgent and the incumbent faction has taken place. I regard two assertions as legally determinative of the argument being made by Professor Moore:

(1) Covert assistance, even of a substantial nature, to an insurgent faction does not constitute an armed attack;

(2) Counter-intervention on behalf of an incumbent faction may not extend the conflict beyond its existing territorial boundaries.

guities and antagonistic misperceptions that are likely to accompany a conflict of the Viet Nam variety make it very important for states to limit their involvement to the boundaries of the society wherein the violence is loated. 
This reasoning seemed directly applicable to the situation in Viet Nam with the consequence that the extension of the war to the territory of North Viet Nam by the United States is deemed to be a violation of international law.

Professor Moore, if I understand him correctly, argues:

(1) My Type II paradigm confuses what the rules of international law ought to be with what the rules actually are;

(2) The weight of legal authority supports Saigon's discretion to treat North Viet Nam's aid to the N.L.F. as an armed attack and thereby authorizes defensive measures undertaken against North Vietnamese territory;

(3) Bombing North Viet Nam has been a reasonable defensive measure for the United States to undertake on behalf of South Viet Nam in view of the facts of attack and the law authorizing a proportionate response to it;

(4) The policy interests at stake are more consistent with such discretion than with the territorial limitations embodied in the Type II paradigm. Thus Professor Moore concludes there is "greater reason [than not] to believe both as a matter of the is and the ought that the bombing of the North is a permissible defensive response."

The Distinction between "Is" and "Ought" in the Context of Viet Nam: The Doctrinal Level of Discourse

I find it peculiar that Professor Moore argues, on the one hand, that the ambiguity of the legal and factual setting in Viet Nam makes it essential to assess the respective rights and duties of the parties by reference to the world order policies at stake, and on the other that my major line of legal analysis confuses what the law ought to be with what the law is. It is peculiar that Professor Moore should rely on Hans Kelsen, an arch-positivist, to support a critique that is explicitly couched in terms of the sociological jurisprudence of Myres McDougal, especially when Kelsen is invoked to show what is meant by the phrase "armed attack" as it appears in Article 51 of the Charter. Of course, Kelsen stresses the dichotomy between the "is" and the "ought," but it is this stress that seems quite contrary to Moore's assertion, one that I share, that international law is above all a process whereby actors clarify through their conduct the world order policies that each deems decisive in a particular context. For sake of clarity of discussion I shall try, despite this jurisprudential ambivalence that I detect in Professor Moore's critique, to respond directly to his analysis. 
Does Type II Embody a Preference About What International Law Ought to Be?

Type II acknowledges the indeterminacy of international law with respect to intervention and counter-intervention. There is no weight of legal authority that can be crystallized in terms of rules commanding universal, or even widespread respect. In fact, respectable and responsible international jurists disagree as to whether international law:

(1) allows discrimination in favor of the incumbent; ${ }^{\text {cs }}$

(2) requires impartiality as between the incumbent and the insurgent; 6 :

(3) allows discrimination in favor of the just side. ${ }^{.5}$

In face of this indeterminacy it seems useful to acknowledge the extent of sovereign discretion as to participating in a foreign civil war. International law does not provide authoritative rules of restraint, or stated more accurately, it provides contradictory rules of restraint of approximately equal standing. To invoke international law in this international setting, then, is to argue about desirable policy or to communicate in precise form what a particular state intends to claim; international law does not, however, postulate rules of order the transgression of which is illegal.

One of the authorities relied upon by Moore, Ian Brownlie, an international lawyer in the strict positivist sense, gives the following support to insisting upon the applicability of territorial restriction in a Type II situation:

When foreign assistance is given to the rebels, aid to the government threatened is now generally assumed to be legal. TWhether

63. E.g., Professor Moore (1080-93) and Garner, Questions of International Law in the Spanish Civil War, 31 AM. J. INT'L L. 66 (1937); see also Borchard, "Neulrality" and Civil Wars, 31 AM. J. INr'L L. 304 (1937).

64. E.g., Wright, supra note 60, and W. HALx, INTERNational LAW 347 (8th cd. 1924).

65. This position has been enunciated in its classical form by E. VATTE, TIE LAW OF Nations, Bk. II, § 56, 131 (1916). Although positive international law promotes either discrimination in favor of the incumbent or impartiality, the practice of states increasingly vindicates giving help to the side deemed "just." From the perspective of world order it is crucial to develop community procedures to identify which side is "just." Such procedures seem to work for those situations in which the principal rival states have apparently converging interests, as with the unresolved problems of bringing independence and racial equality to Rhodesia, South WVest Africa, Angola, Mozambique, and South Africa. But where rival principal states disagree, as when civil strife between "mdical" and "conservative" elites occurs in the developing countries, then the determination of which side is "just" is likely to generate competitive interventions if the contradictory perceptions are acted upon. The Communist ideas of support for wars of national libers. tion are in conflict with American thinking on the legitimacy of helping any anti. Communist regime sustain itself against Communist opposition. In a vorld of antagonistic ideologies it is dangerous to maintain complete discretion on the national level to identify which faction is "just"; but, equally, in a world of insistent legislative demands it is dangerous to preclude discrimination in favor of an insurgency that is deemed just by the overwhelming consensus of international socicty. One approach for Cold War issues and another for Southern African issues seems imperative at this point. 
this is permitted in relation to minor disturbances caused by foreign propaganda or other forms of interference is an open question. It is also uncertain as to whether the foreign assistance must be a decisive element in the imminent and serious threat to the existing government or whether it is sufficient if foreign assistance is a contributory cause. Finally, foreign assistance to the government will be confined to measures on the territory of the requesting state unless the foreign aid to the rebels amounts in fact and law to an "armed attack" (emphasis supplied). ${ }^{66}$

It is worth noticing that Brownlie attributes uncertainty to the positive law in this area, but more immediately, it is important to take account of his reliance upon territoriality as a limiting criterion. Brownlie reinforces the quoted passage in the course of his discussion of claims to use force in self-defense against alleged aggression:

It is suggested that so far as possible defensive measures should be confined to the territory of the defending state and the hostile forces themselves unless there is clear evidence of a major invasion across a frontier which calls for extensive military operations which may not be confined merely to protecting the frontier line. The precise difficulty in the case of indirect aggression is to avoid major breaches of the peace of wide territorial extent arising from defensive measures based on vague evidence of foreign complicity. ${ }^{67}$

It seems reasonable to regard Brownlie's discussion as a generalization of past state practice that reflects international law. My Type II boundary rule places an outer limit on the discretion of the sovereign state and is precisely the kind of quasi-objective limit that is so crucial for the maintenance of world order.

It is correct, as Professor Moore argues, that if the insurgent faction is the "agent" of the outside state then it is permissible for the victim state to respond at the source by regarding the apparent insurgency as an armed attack. But such a response requires a real demonstration of

66. I. Brownle, International LAw aNd the USE of Force by States 327 (1963). See also Pinto, Les Règles du Droit International Concernant la Guerre Givile, RrGutiL DES COURS 451, 544-48 (1965).

67. Id. 373, "Indirect aggression and the incursions of armed bands can be countered by measures of defence which do not involve military operations across frontiers." Id. at 279. A recent Western visitor to North Viet Nam confirms the distinction between inter. vention in the South and bombing of the North as vital to the North Vietnamese per ception of themselves as victims of United States aggression:

Their [North Viet Nam] position is that the bombing of the North is a separate act of aggression from fighting in the South. While they might understand and tolerate, although disapprove, American intervention in the South on behalf of the Saigon government, they regard the bombing of the North as an unconscionable act of aggression against a sovereign nation.

Ashmore, supra note 21 , at $17,12,14$. 
instigation and control, as distinct from either a mere allegation or evidence of some assistance to a faction that appears to possess an independent character and objectives.

International law is not really indefinite on this subject. A state is not permitted to use sustained military force against a foreign country unless the justification is overwhelmingly clear. ${ }^{63} \mathrm{It}$ is difficult to establish unilaterally that covert uses of force by an external enemy can ever constitute an ample justification. It is difficult to distinguish a pretext from a justification, especially as the status of assistance to either side in an ongoing civil war seems legally equivalent. That is, one side may discriminate in favor of the incumbent, whereas the other side may discriminate in favor of "the just" faction, and both possess an equal legal basis. ${ }^{69}$ In such a situation any serious concern with the policies of conflict minimization would insist, at least, that neither side has the discretion to extend the war to foreign territory.

The dynamics of internal war are such that both sides must, as the war progresses, almost certainly seek increasing external support to maintain their position in the struggle; if the scene of the internal war is a minor country then it is increasingly likely that both factions will become dependent for their political leadership upon a larger external ally. ${ }^{70}$ Insurgent dependence on external support is not by itself proof of an aggressive design on the part of the supporter state. This dependence on an external ally is normally only an expression of the changing ratios of influence between the benefactor and recipient of military

68. Action and reaction sequences involving "incidents" have not been regulated in any very clear and definite way by international law. States interact by claim and counterclaim and the degree of legality is very largely dependent on the general impression of the reasonableness of the action undertaken by the contending states. The Guif of Tonkin incident was a characteristic illustration of this process. The legality of the United States response depends primarily on (a) the reality of the provocation and (b) the proportionality of the response. For useful background as to practice, policy, and law in this kind of setting of sporadic violence see F. GROB, TuE RELATIVITX OF WAR AND Peace: A Study in Law, History, and Pormitos (1949).

69. This flexibility of international law is confirmed by the discretion states posess to accord or withhold recognition from a partially successful insurgency. I. CuEs, T11E INTERNATIONAL LAW OF RECOGNITION (Green ed. 1951). It is not necessary for recognition to be accorded in an express or formal manner. De facto recognition arising out of intercourse between the third-party state and the anti-government faction is sufficient provided the facts of the civil war justify the inference of dual sovercignty; i.e., each faction governs a portion of the society and this situation is likely to continue for a considerable period of time. As Lauterpacht concludes, "It is not contrary to international law to recognize the insurgents as a government exercising de focto authority over the territory under its control." H. LAUTERPACHT, RECOGNITION IN INTERNATIONAL IAW 294 (1917). See generally id. 279-94.

70. The process by which an internal war is internationalized is well-depicted in Modelski, The International Relations of Internal War, in INTERNATIONAL ASPECTS OF Civil Strife 14-44 (J. Rosenau ed. 1964). 
assistance on both sides as the conflict progresses to higher magnitudes. It would be detrimental to world order to treat such ratios as equiva. lent to an armed attack by one state on another and prior to the war in Viet Nam there had been neither serious juridical support nor diplomatic practice that would justify treating assistance to an insurgent as an armed attack. In fact, for world order purposes, bombing North Viet Nam has to be appraised as if it were seeking to establish a new legal precedent upon which other states could and should subsequently rely. ${ }^{71}$

Professor Moore regards as "mysterious" my assertion that bombing North Viet Nam is simultaneously both

(1) a violation of international law and

(2) a law-creating precedent.

It may be mysterious, but it is a mystery locked into the international legal process. As a consequence of the absence of a legislature in international society, the assertion of a claim by a state to act in a certain way, if supported by an appeal to the policies and rules of law and if effectively asserted in practice, is both a violation of law as measured by prior expectations about what was permissible in a given situation and a precedent that can be subsequently invoked to legitimate future conduct of a similar sort. This can be stated more concretely by asking about whether prior to the war in Viet Nam a response against the territory of the state assisting an insurgent faction was regarded to be as permissible as it might be in some subsequent war of the Viet Nam variety. ${ }^{72}$ Certainly, the precedent of Viet Nam will provide valuable support for any victim state that attacks foreign territory on

71. The international law applicable to Type II situations is subject to "Iegislative" modification by principal states asserting new claims in an effective fashion and defending their assertion by an appeal to international law. It would be very difficult for the United States to oppose the legal argument it has developed to support its claim to bomb North Viet Nam. In this respect, my criticism of the Meeker legal rationale for "selfdefense" in Viet Nam is more that it constitutes bad "legislation" than that it is "a violation." But cf. Meeker, supra note 23. Often a precedent established for one context can be successfully invoked for different objectives in a series of subsequent contexts. This general process is very ably depicted in connection with the activities of the International Labor Organization by Ernst Haas. See E. HAAs, BEYOND THE NATION-STATE, esp. 381.425 (1964) (describing precedent-creation in a cold war context later being invoked in anticolonial and anti-racist contexts with regard to "freedom of association").

72. The United States has not even restricted bombing to certain specific objectives related directly to the Vietcong war effort-for instance, the specific interdiction of supplies and infiltrators or destruction of staging areas. President Johnson explicitly includes punishment as one of three principal objectives of bombing North Viet Nam: "[W]c sought to impose on North Viet Nam a cost for violating its international agrcements." President Reviews U.S. Position on Bombing of North Viet-Nam, 56 DEP'T STATE BUL.، 514,515 (1967). For a description of the impact of bombing on North Viet Nam see H. Salisbury, Behind the Lines-Hanol December 23-January 7 (1967). 
the ground that it was substantially assisting the insurgent. Other international settings in which a legally dubious claim was converted by its successful assertion into a legally authoritative precedent can be mentioned-for instance, testing nuclear weapons on the high seas, orbiting reconnaissance satellites, and imposing criminal responsibility upon individuals who lead their country in an aggressive war. Professor Moore once again appears hesitant to accept the full jurisprudential implications of the McDougalian orientation that he advocates: if there is a process of law-creation at work in international society, then the distinction between a violation and a law-creating precedent is one of perspective and prediction, but not logic.73

Is North Viet Nam's Assistance to the N.L.F. "an Armed Altack?" The Factual Level of Discourse

Only if North Viet Nam's assistance to the N.L.F. can be considered an armed attack, is proportionate self-defense available to Saigon and its allies.

Professor Moore argues that North Viet Nam is guilty of an armed attack on South Viet Nam for the following principal reasons:

(1) A substantial body of scholarly opinion holds that Hanoi actually initiated, as well as assisted, the insurgency;

(2) Hanoi exercises control over the activities of the N.L.F.;

(3) Hanoi's principal objective is to reunify Viet Nam under its control; therefore, its assistance is, in effect, a project for the territorial expansion of North Viet Nam at the expense of South Viet Nam.

These issues concern the quality, quantity, and phasing of Hanoi's role. Reasonable men disagree about the facts. Many observers, especially in the United States, regard the resolution of these factual questions as critical to their assessment of whether the United States has responded in a lawful manner. For purposes of my own analysis I would argue that even if the facts are accepted in the form that Professor Moore presents them the conflict in Viet Nam is appropriately treated as Type II. I would additionally argue, however, that Professor

73. This process is summarized in part by the maxim ex factis jus orilur; without legislative organs and without a general conference procedure, the growth of international law reflects the process by which claims and counter-claims interact, especially if principal states are participants.

It is, of course, possible to distinguish an arbitrary recommendation of a particular author as to preferred regulatory schemes from a reasoned application of pre-existing community legal policies to a controversial fact situation. In the former ase one is dealing with a criticism of the legal order, whereas in the latter one is concerned with an application of law, albeit an application that interprets obligations in light of policy preference. 
Moore's construction of the facts relies on the reporting of biased observers. Furthermore, I would contend that it is inappropriate to appraise Hanoi's connection with the N.L.F. without taking into account Washington's connection with the Saigon regime, especially after the insurgency had succeeded in establishing itself as the government for many areas of South Viet Nam.

\section{Construing the Controverted Facts}

The ambiguity of the facts in a situation in which civil strife has been allegedly abetted by external assistance is one reason why it is important to regulate the scope of conflict by objective limits. It is obviously easy for any interested state to manipulate the evidence to vindicate any response. The gradual emergence of a serious struggle for the control of South Viet Nam gave the Saigon regime and the United States an adequate opportunity to establish the facts by impartial procedures and to have recourse to international institutions to vindicate the legal inferences of "aggression," and later, "armed attack," that were drawn from the facts. It is important to realize that the United States made very little effort to secure wider community support for its preferred course of action in the decade after the Geneva settlement of $1954 . .^{74}$

Furthermore, recourse to self-defense was not prompted by any sudden necessity. It was decided upon in February, 1965, with considerable deliberateness after consideration over a period of months, if not years. ${ }^{75}$ In this circumstance, the burden of justification seems to fall heavily on the United States for the following reasons:

(1) the essential ambiguity of the alleged aggression, especially in view of the refusal of the Saigon regime to implement the election provisions and its suppression of all political opposition;

(2) the non-recourse to the organs of the United Nations, despite the time available and the refusal to adopt the war-terminating suggestions of the Secretary General; ${ }^{70}$

(3) the absence of a clear showing of necessity and justification required in contemporary international law to validate the exercise of the right of self-defense;

74. Consultative Council 7l-76.

75. See the original official explanations for bombing North Viet Nam in BAckGround INFORMATION 148-52, and the more recent explanation in 56 DEP'T STATE BULL. supra note 72.

76. Compare Falk, supra note 1, at 1140-43, with text of Goldberg's Letter to the Secretary General on December 19, 1966, N.Y. Times, Dec. 20, 1966, at 6 , col. 4 , and excerpts from U Thant's introduction to the annual report on the work of the United Nations, Sept. 19, 1966, at 18, col. 5. 
(4) the consistent previous international practice of confining civil strife, even in cases where the insurgent faction was aided and abetted by outside powers, to territorial limits;

(5) the locus of conflict being outside the immediate security sphere of the United States, thereby distinguishing the protective role exhibited by United States diplomacy in Latin America. ${ }^{77}$

These factors in the Viet Nam context are mentioned to indicate the legal background. Such a background seems to require, at minimum, a clear demonstration that the facts are as the United States contends. The so-called "white papers" issued by the State Department ${ }^{78}$ are considered to be too one-sided even for Professor Moore. Instead he relies heavily upon Douglas Pike, author of a detailed study entitled Viet Cong, written at the M.I.T. Center for International Studies, during a one-year leave of absence from his role as an official of the United States Information Agency;i0 Mr. Pike had spent the preceding six years serving in Viet Nam, during which period the research was done. One need not be an editor of Ramparts to note that M.I.T.'s Center has long been subsidized by the C.I.A. and has given consistent guidance and support for United States foreign policy, especially with regard to the containment of communism; a list of Center publications indicates a consistent pro-Administration outlook. Mr. Pike's analysis certainly deserves careful reading, and is to some degree endorsed by Bernard Fall's interpretations, but the prospects of bias must be noted and his conclusions must be carefully tested against those reached by neutral observers. ${ }^{80}$ In responding to Professor Moore,

77. There are broad deferences accorded to principal sovercign states to prevent hostile political changes in countries located within 3 traditional spliere of inlluence; these interferences, although vigorously controversial, do not generally endanger international peace and security because a principal state is reluctant to use force in a rival sphere of influence. Such geo-political toleration is not intended to serve as a juridieal vindication for unilateral interventionary practices that have been solemnly renounced. For a legal critique of intervention carried on within a sphere of infuence sce Falk, American Intervention in Cuba and the Rule of Law, 22 Omo ST. L.J. 546 (1961); this analysis applies a fortiori to the 1965 intervention in the Dominican Republic.

78. U.S. Dep't of State, A Threat to the Peace: Nortit Viet-NAas's Effort to

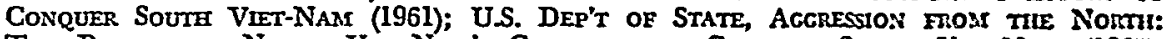
The Record of North Viet-Naxi's Gaxipaice to Conquer South Viet-Nais (1965), (reprinted in 52 DEP'T STATE Butr. 404).

79. D. Pike, Vietcong: The ORganization and Techinigues of the National Luberation Front of South VIETNaAr (1966) [hereinafter cited as PIKE]; see also the apparent deception in an earlier attempt to show that Hanoi dominated the N.L.F., wherein the author's C.I.A. affiliation was disguised by presenting him as "a student of political theory and Asian affairs ... former officer in U.S. AID Mission in Saigon; author of "Aestheties and the Problem of Meaning." " Carver, Jr., The Faceless Pietcong, 44 Foreicn AFFalrs 347 (1966).

80. Among other unintended conclusions that emerge from Pike's study is the clear sense that the National Liberation Front possesses the organizational efficiency, cohesion, and talent to govern South Viet Nam in a manner never achieved by the Saigon regime. 
I would argue that by relying as heavily on Mr. Pike (without taking serious account of the significantly different interpretations of Jean Lacouture, George Kahin and John Lewis, and Bernard Fall) he bases his conclusions of fact on ex parte presentations which, due to an appearance of academic impartiality, are more misleading than "the White Papers" he dismissed as "one-sided." 81

Space permits me only to give two illustrations of why, aside from his vested vocational outlook, I find it difficult to regard Mr. Pike as a trustworthy guide to the facts in Viet Nam. The Preface ends with this rather emotional statement of Pike's personal commitment to the United States role in Viet Nam:

The plight of the Vietnamese people is not an abstraction to me, and I have no patience with those who treat it as such. Victory by the Communists would mean consigning thousands of Vietnamese, many of them of course my friends, to death, prison, or permanent exile. ... My heart goes out to the Vietnamese people-who have been sold out again and again, whose long history could be written in terms of betrayal and who, based on this long and bitter experience, can only expect that eventually America too will sell them out. If America betrays the Vietnamese people by abandoning them, she betrays her own heritage. ${ }^{82}$

What is striking about this passage is its identification of "the Vietnamese people" with the American support of the Saigon regime. Does not Mr. Pike think that if Marshal Ky prevails "thousands of Vietnamese" would be consigned "to death, prison, or permanent exile"? This is what happened to the anti-Diem opposition in the South after 1954 (and, incidentally, to the anti-Ho opposition in the North), and it is a common, if tragic, sequel to a bitter civil war. To associate the prospect of such oppression exclusively with an N.L.F. victory, as Pike does, is to endorse the most naive and sentimental American

From the perspective of international order the capacity to govern is certainly an element in claiming political legitimacy. A second unintended conclusion is the extent to which Hanoi's increasing influence upon the N.L.F. has been a direct consequence of the American entry into combat operations. This increase in influence has, according to Mr. Pike, temporarily at least submerged real differences in outlook and objectives be. tween the N.L.F. and Hanoi, differences that belie the more general hypothesis that the N.L.F. is a creation and creature of Hanoi's conjuring.

81. See, e.g., Max F. Millikan's Foreword in which he stresses the academic and disinterested character of the Center for International Studies and its sponsorship of Mr. Pike's inquiry. PIke, v-vi.

82. Id. at xi-xii.

83. Cf. R. W. Apple, Jr., N.Y. Times, May 17, 1967, at 3, col. 2, describing the activities of Miss Cao Ngoc Phuong in organizing a non-Communist, Buddhist opposition to the Saigon regime's war policy and the harassment to which she has been subjected by Premier Ky's police officials while trying to carry on her activities. 
propaganda. Also Pike's passage indicates the emotional character of his commitment to "the American mission," a commitment that is unqualified by any reference to the doubtful claims to rulership possessed by the present Saigon leadership. ${ }^{84}$

When Pike explains the creation of the N.L.F. his bias appears in the form of the following undocumented conjecture:

The creation of the N.L.F. was an accomplishment of such skill, precision, and refinement that when one thinks of who the master planner must be, only one name comes to mind: Vietnam's organizational genius, Ho Chi Minh. ${ }^{85}$

Even Pike suggests that prior to the emergence of the N.L.F. in 1960 there had been sustained resistance to the Diem government by "Communists, the religious sects, and other groups." 80 The point is that even a biased accounting of the facts is compelled to take account of the pre-Communist and non-Communist role in the early years of the insurgency. ${ }^{87}$

84. Consider, for instance, the inconsistency between the claims of a democratic society in South Viet Nam and the Constitution approved by the Constituent Assembly in 1967. See, e.g., Article 5: "1. The Republic of Viet-Nam opposes communism in every form. 2. Every activity designed to propagandize or carry out communism is prohibited"; Article 81(2): "The Supreme Court is empowered to decide on the dissolution of a political party whose policy and activities oppose the republican regime." For the text of the Constitution, see the Congressional Record (daily ed.) for June 6, 1967, S 7733-37.

For a full account of the terror that commenced in 1954, see 2 Burmicen 893.916.

85. PIRE 76.

86. Id. 75. This non-Communist resistance to Saigon has also been emphasized by Bernard Fall's accounts of the early phases of the insurgency. And as recently as May 1967, Miss Cao Ngoc Phuong, who according to R. W. Apple, Jr., of the New York Times, "is regarded as a heroine by peace-oriented intellectuals in South Vietnam," is quoted as saying:

Many of my friends seem to have joined the Vietcong. Wve are losing the blite of our country. These people know the National Liberation Front is closely allied, with the Communists and we don't like Communism. But they see no future in this [the Ky] Government

N.Y. Times, May 17, 1967, at 3, col. 2.

87. 2 ButrINGER $972-92$ contains a very balanced account (but one written from an anti-Communist perspective) of the origins of the Second Indochina War during the Diem regime. Buttinger writes that "The Diem Government itself created the conditions that pushed the population to the brink of open rebellion, and this convinced the Communist leadership that the South could be conquered by force," id. 977. Buttinger believes the "concerted effort to overthrow the Diem regime and its successor by force, was organized by the Communists, and while it would have made little headway without vide popular support, neither would it have had its amazing success vithout guidance and assistance from the North.

"But the Saigon-TWashington version of these events, which had been reduced to the flat assertion that 'the Vietnam war is the result of external aggression' strays even farther from historical truth. Neither the strenuous efforts of Saigon nor those of Washington have produced evidence that anti-Diem terror and guerrilla warfare started as a result of infiltration of combatants and weapons from the North. No signifiant infiltration occurred before 1960, and very little during the next three years." Id. at 981-82. Even according the North as substantial a role as Buttinger does, great doubt is still cast on the American inference of "external aggression," without which Professor Mfoore's entire legal edifice is without proper foundation. 
But if one turns to disinterested observers the situation looks significantly less supportive of the official American factual account. Jean Lacouture ${ }^{88}$ wrote in May, 1966:

In the beginning most people in the National Liberation Front (N.L.F.) were not Communist, although more are becoming Communist day by day. . . . Until 1963, at least, the Communists were a minority in the N.L.F., and if they found it necessary one year before to create the People's Revolutionary Party (P.R.P.) within the heart of the N.L.F., it was precisely to bolster their inadequate influence. ${ }^{89}$

Lacouture also shows that the evidence of Hanoi's influence on the N.L.F. is very tenuous as a consequence of differences in the style and contents of its texts relevant to the war. ${ }^{90}$

It would appear, then, that impartial interpretations of the role of Hanoi in aiding the N.L.F. do not significantly support Professor Moore's factual inferences. ${ }^{91}$ At best, the factual situation in Viet Nam is ambiguous with respect to the relations between North Viet Nam and the N.L.F. ${ }^{92}$ Each side resolves the ambiguity to suit the image of the war that it seeks to rely upon. I am convinced that the facts, although ambiguous in some particulars, do not support equally convincing interpretations by the supporters of Saigon and by the supporters of Hanoi; I am convinced that the weight of the evidence and the burden of impartial commentary lends far closer support to Hanoi's version of "the facts" than it does to Saigon's version. But, for sake of analysis, let's assume that the ambiguity supports equally convincing, if mutually inconsistent, accounts of the role of Hanoi in the creation, control, and outlook of the N.L.F. Even so, neither legal precedent, nor legal commentary, nor sound policy analysis, supports the

88. Jean Lacouture is a distinguished correspondent for Le Monde who has written extensively on Viet Nam for more than a decade, and holds a strongly anti-Communist position.

89. Lacouture, The "Face" of the Viet Cong, WAR/PEACE REPORT, May 1966, 7 (written as a reply to Mr. Carver's article in ForEIGN AFFAIRs, supra note 79); $c f$. Kanin AND LEwis 109-16, especially at 109: "When the deadline for the promised election passed in July 1956, Hanoi Radio continued to counsel moderation and peaceful tactics to its Southernbased supporters.

"For the next two years revolts against Diem emanated primarily from non-Vietminh quarters."

90. Lacouture, The "Face" of the Viet Cong, WAR/PEAcE REPORT, May 1966, at 8.

91. KAHIN \& LEwIS 110-16.

92. It is not only the facts as such, but their interpretation that is subject to disagree. ment. The interpretation of the Vietcong's character depends on the orientation of the interpreter toward such related matters in the Viet Nam setting as Afro.Asian nationalism, the Saigon regime, the effects of American involvement, and the kind of society that would evolve from the various alternative lines of development open to South Vict Nam (including reunification with the North). 
United States' contention, as of February, 1965, that North Viet Nam had committed "an armed attack." Such a claim to strike back virtually eliminates all legal restraint upon the discretion of a state or its allies to transform an internal war into an international war. As such, it repudiates the entire effort of twentieth century international law to fetter discretionary recourse to force by a sovereign state. In addition, in a situation of ambiguity the burden of asserting the right to use military power against the territory of a foreign country should be placed upon the claimant state. This burden is especially difficult to sustain when the claim to use force is generalized rather than being justified as a proportionate response to some specific provocation or being directed at some specific external target relevant to the internal war, such as a sanctuary or infiltration route. The United States has increasingly claimed for itself the right to bomb whatever it deems appropriate without restraint as to time, target, or magnitude.

\section{Oppression by Saigon as a Causative Agent}

Professor Moore's contextual account is strangely devoid of any reference to the effects of Premier Ngo Dinh Diem's reign of terror in the 1956-57 period in South Viet Nam. Bernard Fall, among others, points out that the uprising of peasants against Saigon arose as a consequence of Diem's policies that pre-existed the formation of the Vietcong and was accomplished without any interference on the part of Hanoi. ${ }^{93}$ It is difficult to establish causal connections in the Viet Nam setting, but any account of how the violence started in South Viet Nam should call attention to the priority in time, as well as to the oppressiveness and social backwardness of the Diem regime.

It seems worth considering the account given by Joseph Buttinger, an ardent anti-Communist and the most knowledgeable narrator of the relevant historical period (World War II to the assassination of Diem in 1963). ${ }^{94}$ Buttinger calls " $[t]$ he manhunt against the Vietminh [the coalition of Vietnamese forces that had fought against French colonialism] an almost incomprehensible violation of common sense, and one of the major contributions to the success of the later Communist-led insurrection." 95 In addition to spreading terror throughout South Viet Nam there were "an unending series of sermons about the

93. B. FALL, THE Two VIET-NaMs (1st ed. 1963) 272: "the countryside largely went Communist in 1958-60," i.e., before the Vietcong came into existence. [Quoted in 2 BUTIINGER 977.]

94. 2 BUTTINGER 974-81.

95. Id. 975 . 
evils of Communism, delivered in compulsory meetings by officials whom the peasants had every reason to despise." 00 The victims of Diem's oppression included many non-Communists; "[e]fficiency took the form of brutality and a total disregard for the difference between determined foes and potential friends." was the form of governmental action in this pre-Vietcong period in the South when there was only an apprehension about a Communistled insurrection, but no action. Buttinger gives an explanation of why Diem's reign of terror did not provoke official American protest that exposes the root of the Viet Nam tragedy: "The American public, which a little later was told of the many Diem officials murdered by the so-called Vietcong, learned nothing at all about these earlier events, not so much because of Saigon's censorship but rather because of the West's reluctance openly to condemn crimes committed in the name of anti-Communism." 98 It is this ideological biasing of perception that has led the United States Government and its supporters to believe in the rationalization of the war in Viet Nam as defense against aggression. To give Diem and his successors the kind of backing that we have given him can only be explained as part of a global crusade against the spread of Communist influence. ${ }^{.8}$

\section{The Relevance of United States Aid to the Incumbent Regime}

The inference of "armed attack" must include an examination of the overall relevant context. But Professor Moore ignores altogether the relevance of the United States connection with the Saigon regime to an appraisal of Hanoi's role. The assistance to the N.L.F. given by Hanoi takes on a very different character if interpreted as neutralizing the assistance given by the United States to the other side in an ongoing civil struggle. 100 International law does not prohibit discrimination

96. Id.

97. Id. 976.

98. Id. (emphasis added).

99. This understanding of the American commitment must have prompted $U$ Thant in the Introduction to the Annual Report on the work of the United Nations in 1966 to say: "I see nothing but danger in this idea, so assiduously fostered outside Victnam, that the conflict is a kind of holy war between two powerful political idcologies." N.Y. Times, Sept. 19, 1966, at 18, col. 5. Stillman and Pfaff write in a similar vein in the course of a major analysis of U.S. foreign policy: "Our dominating impulse in Vietnam is ideological; the conventional political and strategic justifications for the American involvement in Vietnam seem peripheral, and even doubtful." E. StillataN \& W. PFAFF, Powek AND IMPOTENCE 171 (1966).

100. Consider the relevance of these words of John Stuart Mill:

But the case of a people struggling against a foreign yoke, or against a native tyranny upheld by foreign arms, illustrates the reasons for non-intervention in an opposite way; for in this case the reasons themselves do not exist. . . . To assist a people thus 
in favor of an insurgent, especially one that has already enjoyed a degree of success, who is deemed to be "just" nor does it prohibit counter-interventionary efforts designed to offset intervention on behalf of the incumbent. ${ }^{101}$ The policies of self-determination at stake are best served by an attitude of impartiality. The coercive apparatus of the modern state is able to suppress even very widely based popular uprisings; the evolution of social control increasingly favors the government in a domestic struggle. The advantages of the domestic government are accentuated by its normal intercourse with foreign states, including its option to continue to receive foreign aid. If peaceful domestic opposition is disallowed and a coercive government is aided by a powerful external ally, then the sole possibility of approximating the ideas of self-determination is to accord equivalent rights to insurgent or anti-incumbent groups that solicit aid from foreign countries.

If the insurgency succeeds in establishing itself as the de facto government of a substantial portion of the territory in controversy, then foreign states are legally as entitled to deal with the insurgent faction as with the constituted government. Such discretion, expressed in traditional international law by the shifting of insurgent status from "rebellion" to "insurgency" to "belligerency," embodies a sound compromise between according respect to the constituted government as the source of domestic stability and avoiding interferences with the way in which contending groups in a national society work out a domestic balance of forces. This reasoning is applicable to the situation in South Viet Nam. As of 1961, at the latest, the National Liberation Front was in effective control of a substantial portion of South Viet Nam and often was exercising its authority in areas under its control with more success than was the constituted regime in Saigon. ${ }^{102}$ At such a stage in

kept down, is not to disturb the balance of forces on which the permanent maintenance of freedom in a country depends, but to redress that balance when it is already unfairly and violently disturbed. ... Intervention to enforce non-intervention is always rightful, always moral, if not alwyas prudent (emphasis added).

J. S. Mrll, Essays on Polrtics and Culture 412 (G. Himmelfarb ed. 1902).

101. See notes 62-64 supra and pp. 1120-23.

102. Cf., e.g., W. Burchetr, VIETNAM: INSIDE Story of THIE GuerRJLIA TWAR (1965). No friend of the N.L.F., Bernard Fall nevertheless writes that "on the loal level, Amerian sources have privately stated matter-of-factly that the loal NLF administration clearly outperformed the GVN's on every count until the heavy bombardments of 1965.66 made orderly government impossible. It was an established fact that in most areas the NLF did proceed with local elections that were by and lange unfettered-Communist control would exist in the form of a can-bo (a adre) detached to the village chicf for his paperwork-and produced more effective and more popularly supported local government than the country had enjoyed since its loss of independence in the 1860's." B. Farx, Tris Two VIET-NAMS 365 (2d rev. ed. 1967). 
civil strife international law fully allows third-parties to treat the society in question as exhibiting a condition of dual sovereignty. In these circumstances North Viet Nam's assistance to the N.L.F. enjoys the same legal status as does the United States' assistance to the Saigon regime. ${ }^{103}$ Such an interpretation bears centrally on any contention that North Viet Nam committed an armed attack on South Viet Nam subsequent to whatever critical date is chosen to affirm substantial de facto sovereignty by the N.L.F. ${ }^{104}$ The argument of the State Department, then, that the level of support given to the N.L.F. up through 1965 establishes "aggression" of such magnitude as to be "an armed attack" is unresponsive to the basic legal issues at stake. Even accepting as accurate the conclusion that "by the end of 1964, North Viet Nam might well have moved over 40,000 armed and unarmed guerrillas into South Viet Nam" there is no consideration given to the critical fact that as of 1962 the N.L.F. enjoyed enough de facto sovereignty in South Viet Nam to allow North Viet Nam to furnish military assistance on the same legal premises as relied upon by the United States vis-d-vis Saigon. ${ }^{105}$ The whole legal tradition of third-party relationships to contending factions in a civil war is to distinguish the degrees to which a revolutionary struggle has succeeded in establishing itself as a partial "government." Neither the State Department nor Professor Moore take this essential contextual factor into account to any extent in characterizing North Viet Nam's role as "an armed attack."

Given a post-1962 assumption of de facto dual sovereignty in South Viet Nam, third powers are entitled to neutralize and offset external

103. See generally A. Thomas \& A. Thomas, Non-Intervention: The Law and its IMPORT IN THE AMERICAS 215-21 (1956); Falk, The International Regulation of Internal Violence in the Developing Countries, 1966 Proc. AM. Soc. INT'L L. at 58; for the reality and extent of N.L.F. control as of mid-1965 see B. FALג, THE Two VIET NAMs 381, 388 (2d rev. ed. 1967).

104. See especially the basis of argument in the State Department's Memorandum of Law in its opening section vindicating recourse to collective self-defense because of a prior armed attack. Consultative Council 113-14. There is obviously no "armed attack" if the foreign assistance is being given lawfully to one governmental unit in a situation of civil strife in which the adversary unit is receiving a much larger quantity of forcign assistance.

105. That is, the notion of neutrality was supposed to guide third-powers in the event of an ongoing civil war. See, e.g., A. Thomas \& A. THomas, supra note 103, at 219:

A neutral power is always at liberty to decide whether it will permit or will prohibit

aid to the disrupted state; its main duty as a neutral is that it must treat both sides equally.

An obvious corollary of this norm is that when a neutral favors one side, then this advan. tage can be offset by discrimination in favor of the other side. Depending on the phasing of intervention with the existence of a conflict pronounced enough to qualify as a civil war, both the United States and North Viet Nam could reasonably perceive their roles to be one of offsetting or neutralizing the intervention or non-neutrality of the other side. G. White, supra note 3. 
assistance to the other side. Certainly, then, North Viet Nam's military assistance to the N.L.F. seems proportionate to the United States' military assistance to the Saigon regime. Even more certainly, it is unreasonable to characterize North Viet Nam's role after 1962 as "an armed attack" and the United States' role as "lawful assistance." It is also relevant to note that no American official contended that the pre1962 role of North Viet Nam deserved to be regarded as "an armed attack"; even during the debates on the American claims of "reprisal" arising out of the Gulf of Tonkin incident in August, 1964, there was no intimation that North Viet Nam's role in South Viet Nam was of the extraordinary character justifying recourse to "self-defense." It seems clear and significant to conclude that the post-1965 contention of "armed attack" besides being unconvincing on their merits is also an example of arguing post hoc, ergo propter hoc.

In the months immediately after the Geneva Conference in 1954 it was widely believed that the Diem regime would collapse from its own dead weight because of its unpopularity and inefficiency. The United States gave substantial economic and indirect military support to the Saigon government from the beginning of its existence. This support included training, guiding, and paying the main units of Saigon's military establishment. ${ }^{100}$ The United States also played an increasingly significant role in influencing the composition and outlook of Saigon's government, so significant that by the time serious civil strife broke out there was hardly any prospect of resolution being reached by the domestic balance of forces.

As the American military participation on the side of Saigon grew more overt and massive it became clearer that it was Washington and not Saigon that was the main adversary of the N.L.F.107 As Hanoi acted to offset this American military presence in South Viet Nam it was naturally drawn into ever more substantial and overt military participation on the side of the N.L.F. ${ }^{108}$ And certainly since 1963 the United States' control of Saigon's war effort and war aims appears to be much more explicit and decisive than does Hanoi's control over the N.L.F.'s war effort and war aims. Given the ratio of external participation on the two sides of the Viet Nam war it seems contrary both to

106. Kanin \&: Lewis 77-80; The Mansfield Report 20.

107. Increasingly, it became clear that the United States, and not South Vict Nam, was determining the course of the war and the conditions for its settlement.

108. But can one imagine a conference of the N.L.F. allies summoned under the auspices of North Viet Nam in the manner of the 1965.66 conferences at Honolulu, Manila, and Guam? For comparative statistics on foreign involvement in the war in Viet Nam see Kamin \& Lewis I85; B. Fall, The Two Yiet-Nasis 358 (2d rev. ed. 1967). 
the perceptions of common sense and to the dictates of international law to regard North Viet Nam as guilty of an armed attack. The total context suggests that the phasing and extent of the United States participation in the war has had a much greater impact upon its course than has the North Vietnamese participation, and that neither side enjoys a privileged legal status so far as the principles of either self-defense or non-intervention are concerned, at least once it became clear that the insurgent challenge was a serious and prolonged one. In fact, the legal status of Hanoi's role in assisting the insurgency is according to conventional approaches of international law dependent upon the extent to which it is reasonable to regard the insurgent faction as a countergovernment in effective political control over portions of the contested territory. ${ }^{109}$ If Professor Moore stresses the de facto sovereignty of South Viet Nam (regardless of the terms at Geneva), then it seems essential to acknowledge all relevant de facto circumstances including those that benefit the legal contentions of North Viet Nam. In the first Mansfield Report it was acknowledged that "[b]y 1961 it was apparent that the prospects for a total collapse in South Viet Nam had begun to come dangerously close."110

In the context of Viet Nam, however, the normal legal situation is even less favorable to the incumbent regime than it might otherwise be. Chapter III of the Cease-Fire Agreement contains a series of provisions that disallows the incumbent regime its normal freedom to receive military assistance. 111 Article 4 of the Final Declaration "takes note of the clauses in the agreement on the cessation of hostilities in Viet Nam prohibiting the introduction into Viet Nam of foreign troops and military personnel as well as of all kinds of arms and munitions." 112 Therefore, it is arguable that without the authorization of the International Control Commission it was illegal to give any direct military assistance to the Saigon regime; it is also arguable that the United States immediately fostered the violation of the spirit of the Accords by the extension of SEATO to cover South Viet Nam and by the extension of economic aid of such a character that freed Saigon to develop and modernize its military capability as directed by a growing number of United States military advisers. It is difficult to read the Geneva Accords without receiving the strong impression that one of the

109. Cf. note 102 supra and 1135.

110. THE MANSFIEID REPORT 21.

111. Articles 16-18; convenient text of Final Declaration, Consultative Councir 148.50, FURTHER DOcuments RELATING to THE Discussion OF INDOchina AT THE GeNeVA CoNFERENCE (Misc. No. 20) GMD. No. 9239 (1954).

112. Convenient text of Final Declaration, Consultative Counch 148. 
principal purposes was to prohibit post-1954 Great Power intervention in Vietnamese affairs, and given the United States' attempt to mobilize support for a Great Power intervention as an alternative to the Geneva Settlement it is difficult to avoid the conclusion that the provisions on foreign military intervention were directed, above all, at the United States.

Professor Moore suggests that the belligerent objective of North Viet Nam is reunification under Hanoi's control, and he contends that this objective is the functional equivalent of territorial conquest. Such reasoning leads Moore to conclude that Hanoi's assistance to the N.L.F. is more suitably treated as equivalent to North Korea's attack on South Korea than it is to Germany's aid to the Franco insurgency during the Spanish Civil War. I find Professor Moore's conclusion on this point, also, to rest upon a selective interpretation of the relevant context for the following reasons:

(I) Hanoi's pursuit of unification by limited, low-order coercion needs to be understood in light of the outcome of the first Indochina War and the terms of the Geneva Settlement; from the perspective of law North Viet Nam must be accorded a reciprocal discretion in interpreting post-1954 events as is claimed for South Viet Nam;

(2) The evidence advanced by Professor Moore to show that North Viet Nam is seeking reunification is largely hypothetical and speculative;

(3) Both Hanoi and the N.L.F. disavow reunification as an objective of their war effort. ${ }^{113}$

On this basis it seems unconvincing to equate North Korea's sudden and massive overt attack upon South Korea with North Viet Nam's slow build-up of support for the N.L.F. through covert assistance to an insurgent effort against a hostile neighboring regime allied with a hostile superpower. The United States' ill-fated support for the Bay of $P$ igs venture in 1961 was not so long ago. ${ }^{114}$ We went to considerable lengths to disguise our sponsorship of the Cuban exiles intent on overthrowing Castro. Why? Precisely because different world order consequences attach to covert rather than to overt sponsorship of insurrectionary activity in a foreign country. ${ }^{115}$ And what of the role of the C.I.A.

113. Both sides evidently avow peaceful reunification. South Vict Nam goes so far as to incorporate the following two provisions into its new Constitution: Article 1(1): "Vict$\mathrm{Nam}$ is a territorially, indivisible, unified and independent republic" Article 107: "Article 1 of the constitution and this Article may not be amended or deleted." Alay not North Viet Nam espouse a comparable objective? See generally Draper, Vietnam: How Nol to Negotiate, N.Y. REview of Books, Mfay 4, 1967, at 17 .

114. See Falk; supra note 77.

115. See Falk, supra note I, at 1126, n.18. 
in the overthrow of an allegedly pro-Communist regime in Guatemala in 1954? ?11 $^{11}$ I mention these examples of covert interference not to defend this pattern of practice, but to suggest that when the United States has been an active party in support of insurrection a great effort has been made to keep its role as covert as possible for as long as possible. Likewise it was the overtness of our interference with domestic events in the Dominican Republic in 1965 that provoked such intense criticism of our action; it was probably less interventionary than the covert role in Guatemala. ${ }^{117}$ Thus it is not accurate to analogize the covert pursuit of an interventionary policy in a foreign society with its overt pursuit in terms either of its perceived or actual world order consequences, even assuming for the sake of argument that the two modes of interference are equally effective. And therefore, and this is critical for my approach, a unilateral defensive extra-territorial response to covert coercion cannot possibly acquire the same legitimacy as would such a response if made to overt coercion. For these reasons I find it inappropriate to rely upon the Korea analogy; the Spanish Civil War I continue to regard as a helpful precedent because there was no counter-intervention undertaken against the territory of intervening states despite substantial foreign assistance to the insurgent faction.

Type II Geographical Restrictions upon "Defensive" Measures Promotes World Order. The Normative Level of Discourse

Professor Moore argues that the restrictions imposed upon the in. cumbent regime in a Type II situation are arbitrary and that in a particular situation defensive measures against the territory of a state supporting an insurgent ought to be permitted. I would agree with Professor Moore that in a particular war it can be argued that extraterritorial military measures may minimize the extent and duration of destruction. Relevant rules of restraint, however, must be devised with a generality of instances in mind. In the context of a Viet Namtype war I would maintain that Type II restrictions are, in general, desirable. First of all, the appreciation of whether a measure is "defensive" or "offensive" cannot be reliably achieved by interested parties. Second, to the extent that extra-territorial "defensive" measures are justified by the specific characteristics of foreign support, then a

116. D. Wise ANd T. Ross, The Invisible Government (1964). For a relevant account of Guatemala events, see D. Horowitz, From Yalta to Vuetnam $160 \cdot 61$ (1965).

117. For an account critical of the United States intervention in the Dominican Re* public, see J. Fulbrighr, The Arrogance of Power (1966). 
precise claim to use extra-territorial force should be explained in terms of particular military necessities. For example, an air strike directed against extra-territorial insurgent sanctuaries would be more easily justifiable in the context of normal Type II restraints if these sanctuaries bore a significant specific relationship to the conduct of the war. But bombing North Viet Nam has not been justified in terms of specific, limited military objectives requiring exceptional action; in fact, the American rationale for bombing North Viet Nam has changed character from time to time and the scope and intensity of the bombing action appear disproportionate to the military justification. In addition, independent, non-Communist world public opinion almost universally condemns the continuation of bombing by the United States and the Secretary General of the United Nations has repeatedly called upon the United States to stop bombing on a unilateral and unconditional basis. Hanoi, too, has insisted that the unconditional termination of bombing is the essential precondition for peace talks. The United States' effort to negotiate a reciprocal de-escalation by North Viet Nam in exchange for a halt in bombing overlooks both the general attitude in opposition of the bombing and the inequality in bargaining power that exists between the greatest military colossus in world history and a tiny war-torn and unmodernized state.

Third, the frequency of patterns of intervention and counter-intervention in civil strife throughout international society underlines the danger of spreading violence beyond its original national locus. Greece and Turkey in Cyprus and the United Arab Republic and Saudi Arabia in the Yemen are two examples of civil struggles that could grow much worse if the external sponsor of the incumbent regime felt entitled and did, in fact, attack the territory of the insurgent's external sponsor. ${ }^{118}$ It does not require much knowledge of fire-fighting to conclude that confining the spatial scope of a fire is one way to restrict its damaging impact.

If the coercion is sustained and substantial then the prospects of dealing with it by community procedures are improved. Because of the ambiguity of the facts and the tendency to interpret them in a selfjustifying fashion in the Viet Nam setting it is important to restrict

118. In fact, one would imagine a serious regional war emerging if cither side trans. gressed the limits that $I$ argue are embodied in a Type II conflict. Only the mutual forbearance of both sides, despite their recriminations about each other's agsression, kceps the conflict at its present level. It is only becuuse the United States is a superpower and North Viet Nam a minor state that the war in Viet Nam has not escalated to much higher levels; it is the power differential that encouraged the United States to transgress Type II restrictions in the spirit of relative prudence. 
responses to the limits of Type II unless a sufficient consensus can be mobilized to shift the conflict into the Type IV category. If it qualifies as a Type IV conflict then the organized international community authorizes the response that is deemed appropriate. Community authorization takes the place of overtness as the key factor vindicating a defensive response against foreign territory. I have already indicated why covert forms of coercion are so difficult to construe, especially in a mixed-up political setting. It follows from this assessment that the resources of world order should be built up to facilitate the authoritative community identification of covert coercion as "aggression." For this reason it would be desirable to establish border-control, factfinding machinery, and peace observation groups in those sectors of the world containing target societies that are highly vulnerable to covert coercion. The objective of these devices is to make covert forms of coercion more visible to impartial observers, facilitating a consensus, legitimating a decisive defensive response, and discouraging recourse to such coercion as a means to resolve international disputes.

My overall approach to Viet Nam-type conflicts has been altered in response to Professor Moore's criticisms in several important respects:

(1) The creation of Type IV to establish an analytic contrast with Types I-III and to permit "self-defense" in the Viet Nam-type setting provided a suitable prior community authorization has been given.10

(2) The realization that aggressive designs can be effectively carried out at present by covert forms of international coercion and that it would be desirable to discourage such coercion by making it more visible; the eventual world order goal would be to treat covert coercion as we now treat overt coercion. The effect would be to make Type II conflicts more easily transferable into the Type IV category or more susceptible to Type I treatment. However, in international society as now constituted it seems clearly preferable to deny the victim state unilateral discretion to treat what it perceives to be "aggression" by covert means as justifying its recourse to "self-defense." 120 In a sense this legal conclusion merely restates the adverse judgment rendered by the international community on several occasions when Israel has

119. A defensive alliance, such as SEATO, only multi-lateralizes decisions to use force to a very slight degree; "the community" must be defined in wide enough terms to include principal divergent elements.

120. This denial is especially justifiable since (a) legitimate defensive interests can be upheld within the terms of Type II, and special exceptions thereto; and (b) shift to Type I tends both to increase the obstruction of international peace and to increase the role of military power differentials in achieving a settlement of an international disputc. 
had recourse to overt military force in retaliation for damage that it has suffered from semi-covert coercion. The rejection of Israel's claim is impressive because Israel has a much more convincing security rationale than does South Viet Nam for striking back overtly and because the Arab states surrounding Israel are avowedly committed to its destruction. ${ }^{121}$ One may argue against the fairness of such constraints upon Israel's discretion in these circumstances, but it is essentially an extra-legal appeal as the organs of the United Nations have the procedural capacity to authorize or prohibit specific uses of force, and it is the exercise of this capacity that most clearly distinguishes what is "legal" from what is "illegal" with regard to the use of force in international society. Legality depends more upon the identily of the authorizing decision-maker than upon the facts of the coercion. With respect to Viet Nam, if a principal organ of the United Nations authorized the United States' bombing of North Viet Nam, then it would be legal (unless an argument could be successfully made that the decision was "unconstitutional"). ${ }^{122}$

Professor Moore also usefully singles out "divided" country problems for separate treatments. He is correct in pointing out that world order is especially endangered by attempts to alter coercively the stalus quo prevailing in a divided country. In this respect the tragic consequences in Viet Nam can be understood as foredestined as soon as Saigon, with the backing of the United States, acted to locate Viet Nam in the divided country category. ${ }^{123}$ The uncertainty as to whether Viet Nam is properly classified as "divided" in Professor Moore's sense involves an interpretation of the Geneva Accords. The classification of Viet Nam as a divided country also appears to have been imprudent in view of the logistic difficulties of securing South Viet Nam against attack and in view of the inability to evolve a tolerable regime in Saigon that could provide South Viet Nam with effective government without a huge American military and economic commitment. ${ }^{124}$ Even without

121. Israel's responses have seemed to conform much more closely to the requirements of proportionality than has the United States-South Viet Nam response, cven if its allegations of coercion are taken at face value.

122. To be legal in the last analysis is to be authorized by the appropriate decisionmaker; one can seek to correct "the mistake" attributed to the decision-maker, but the capacity to confer legality persists so long as the legal order is a valid onc.

123. The seeds of conflict seem to have been sown by the contradictory interpretations of what was "settled" at Geneva in 1954 with regard to the tcrms and timing of reunification; although there is room for some misunderstanding, my orientation is heavily influ. enced by regarding Hanoi's interpretation of the settlement as far more reasonable than Saigon's or Washington's.

124. See the critique advanced by E. Stillaran \& W. Pfaff, Power and Imrotevce 169-74. The opportunity costs of the Viet Nam war are enormous both with respect to the pursuit of international security goals and with regard to domestic velfare goals. 
a hostile North Viet Nam embittered by a sense of being cheated by the non-implementation of the Geneva Accords, there is reason to suspect that without American backing the Saigon regime would have been unable to govern South Viet Nam with any success. Predictions of imminent collapse were widespread until the American military presence assumed major proportions in $1965 . .^{125}$ In addition, there was only minimal and grudging alliance support, much less community support, for regarding South Viet Nam as an inviolable sovereign entity of the same sort as West Germany or South Korea, or even Formosa. For these reasons I do not find it convincing, independent of the issue of ambiguous facts, to analogize Viet Nam to other divided country problems.

III. Comments on Professor Moore's Policy Inquiry vis-à-vis Type III Conflict

Professor Moore's perceptive discussion of the considerations that bear on the international management of intra-state conflict deserves careful study. His stress in the setting of Type III upon the policies of self-determination and minimum world public order points up the difficulty that results from the sort of over-generalization that is implicit in the kind of categorization of international conflict situations that I have proposed. I accept his criticism that my original formulation of Type III rules is "simplistic" if applied mechanically to a large variety of greatly varying international contexts. A complete response to Professor Moore's critique cannot be undertaken within the compass of this article, but will be attempted on another occasion..$^{120}$ I will restrict myself here to a few general comments on Professor Moore's approach to suggest wherein my policy emphasis differs from his with regard to the regulation of third-party participation in intra-state conflict.

Let me say in my own intellectual defense that the division of international conflict situations into three broad categories (now four) ${ }^{127}$

125. KAHIN \& Lewis $66 \cdot 87$.

126. For instance, Types I-IV should be appropriately sub-divided to talie account of recurrent contexts that can be grouped together within each broader category. Thus in Type III there is a difference between the legislative contexts relevant to uprisings in tho five countries of southern Africa, the humanitarian context of slaughter that followed after the generals' counter-coup in Indonesia (1965-66), the anarchy that has been thrcat* ened from time to time in the Congo and Nigeria from prolonged civil strife, and the hegemonial context that exists when one superpower has claimed over time special geo. political prerogatives, acquiesced in by other states, in relation to a region.

127. See pp. 1106-08 for explanation. 
was intended primarily to facilitate and organize thought about the management of all forms of international violence through a preliminary sorting out of relevant contexts and by explicating the decisive legal consequences of each. Once this preliminary task of classification has been accomplished, then it is appropriate to question whether there need to be more specific subcategories and whether rules stating exceptions should not also be included. ${ }^{128}$ On this level, then, my response to Professor Moore is to accept his criticism, but to suggest that the attempt to categorize international conflict appears to add greater focus to policy inquiry than is possible by either an ad hoc response to a specific conflict (Viet Nam) or by a generalized description of the policies bearing most heavily on the legal regulation of recourse to international violence.

On a more fundamental level of policy Professor Moore, as the result of a very sophisticated analysis, appears to conclude that given the conditions of the modern world it is more desirable to endorse an approach to civil strife that authorizes discrimination in favor of the incumbent faction, especially in cold war settings, and prohibits assistance to the insurgent faction.

I am persuaded by Professor Moore's analysis to modify my original formulations to a certain extent. A neutral rule of impartiality does not preclude the continuation of (or even the moderate increase in) the level of assistance furnished a constituted government prior to the outbreak of civil strife. There are, however, restraints upon the scope and form of discriminatory external participation. ${ }^{150}$ For one thing, foreign assistance should not include direct participation in combat operations. For another, it should not attempt to bear more than a fairly small percentage, certainly under 50 per cent, of the increased military requirements created by the domestic uprising. And finally, the external assistance should not be conditioned upon increased influences in the process of decision-making within the recipient country. In the event that the restraints sketched above are ignored, then the conflict is shifted from Type III into the Type II category, the shift itself reflecting "the violation" committed by a third-party state. If the restraints are respected with respect to aid furnished to the incumbent, then substantial aid to instigate or sustain an insurgency is a vio-

128. Note the development of international law governing the use of the cceans as depicted by M. McDougal and W. Burke in The Public Order of the Occans.

129. For a creative effort at emphasizing limits on the character of intervention rather upon its occurrence see Farer, Intervention in Civil I'ars: A Mlodest Proposal, 67 Couvar. L. REV. 266 (1967). 
lation of Type III restraints that shifts the conflict into the Type II category as a consequence of the illegal conduct of the third party.

In the event, however, that the uprising succeeds in establishing control over a substantial portion of the area and population of the country, then a condition of de facto dual sovereignty exists such that third-parties can furnish assistance to the insurgent on the same basis as to the incumbent. If substantial assistance is accorded to one or both sides subsequent to de facto dual sovereignty the conflict is necessarily shifted into Type II, but there is no violation of international law committed by third powers. The internal situation generated a shift from Type III to Type II, as distinct from a shift coming about through interventionary roles by foreign states on either side of a Type III conflict.

If the United States had chosen to give military assistance to the Batista regime in its struggle against the Castro insurgency in Cuba, then this would be permissible unless the United States entered Cuba in the last stages of the war with its independent military capability so as to foreclose the outcome that would have resulted from the domestic balance of forces. The Soviet intervention in Hungary (1956) definitely succeeded in reversing the outcome of a domestic struggle, and was appropriately condemned by the political organs of the United Nations; the United States intervention in the Dominican Republic in 1965 designed to displace the incumbent regime was given presumably an even more objectionable form of decisive external assistance as it was directed against the incumbent faction. ${ }^{130}$

Professor Moore is also correct to suggest that in cold war contexts rules supporting the stability of existing regimes are probably desirable. It may be helpful to restrict pure Type III analysis to the AfroAsian world wherein the geo-political context is of different order. In effect, Professor Moore is pointing out that the rival superpowersthe United States and the Soviet Union-provide their own form of conflict management within those segments of international society regarded as belonging to their respective spheres of influence or adhering to their respective security communities. In this regard it may be helpful to consider that concentric security zones surround each superpower and affect the actual treatment of Type III conflicts to a considerable degree:

I. Primary Security Zone: The United States, the Soviet Union, and

130. For a sympathetic account of the legal basis of the Dominican intervention, sce A. Thomas \& A. THOMAS, supra note 103. 
possibly mainland China and the principal states of Western Europe, as sovereign states in relation to their own national security;

II. Secondary Security Zones: Groups of countries that are traditionally subject to the influence of one superpower or the other and whose security interests are governed by the political preference of the superpower; ${ }^{131}$

III. Tertiary Security Zones: The Afro-Asian world of recently independent states in which policies of non-alignment and non-intervention are affirmed.

These security zones describe the geo-political condition in the world as of 1967. It is a complex world order issue to interrelate these political realities with the role of law in establishing common standards of restraint and interaction. It is generally true that in the Secondary Security Zones the dominant actor is able to exercise control over the outcome of Type III conflicts, although Hungary in 1956 and the Dominican Republic in 1965 were governed by interventions that did not accord generally with permissible uses of military power, at least as understood by general community expectations. ${ }^{132}$

Viet Nam has become such a sustained and major war because the United States has converted a Type III conflict into Type I conflict without the legitimizing benefit of an overt armed attack and without the geo-political tolerance accorded to superporver diplomacy that is confined within its own Secondary Zone. Therefore, the extra-legal categorization of security zones may help to identify those situations in which external military assistance that is carried beyond a certain threshold is likely to trigger a major off-setting military action by a principal adversary. It is now commonplace to note that the most severe forms of international violence since World War II have been the result of competing superpower interferences in the Tertiary Security Zone, especially in those circumstances, such as Viet Nam, where it is unclear whether the territory in dispute belongs in the Secondary Zone, and if so on which side, or in the Tertiary Zone.

Professor Moore's discussion is strangely devoid of any reference to the role of international institutions or to the relevance of the will of the organized international community with respect to the relative

131. E.g., Latin America, East Europe; one might argue that the problems in Asian affairs arise out of China's attempt to establish a Secondary Security Zone on its peripher; and the United States resistance to this attempt.

132. T.e., there is a geo-political level of practice that cxists in a statc of tension with a moral-legal level of commitment; both levels converge in the policy-making process relevant to international decisions. 
merits of contending factions in a Type III situation. ${ }^{103}$ It seems to me that many of the problems that Professor Moore points out, that arise in discriminating between various Type III contexts can be resolved by according regional and global international institutions the competence to identify which faction is entitled to benefit from external assistance. Thus in the context of Southern Africa the decisive expression of the will of the international community would appear to legitimize discrimination in favor of the insurgent faction in the event that a Type III situation should arise at some future occasion; ${ }^{134}$ such discrimination has been stridently endorsed in the African context by the Organization of African Unity. ${ }^{135}$ Types I-III are residual categories that exist only when there is no consensus formally reached by a competent international institution.

A residual rule of impartiality does seem to minimize the role of both extra-national and domestic violence in situations where no international consensus exists. The absence of consensus is itself indicative of a potentiality for major conflict, disclosing seriously opposed interpretations of the appropriate external attitude toward the intra-state conflict. Therefore, in a Type III situation it would seem generally desirable to promote adherence to Hall's view that neither incumbent nor insurgent should be the beneficiary of discrimination. ${ }^{130}$ What level of support for the incumbent constitutes "discrimination" and at what point a civil disturbance is properly regarded as belonging in Type III are complex determinations of fact and law for which no definite answer can here be provided.

Professor Moore, in my judgment, underrates once again the detrimental consequences of affirming the discretion of sovereign states to project their military power into foreign political conflicts. It is true that covert forms of coercion can subject a society to an "attack" that jeopardizes its political independence and territorial sovereignty, but it is also true that "the defense" of that society may involve its destruction and manipulation. To allow discrimination in favor of the incumbent to increase without limit in a situation of civil strife is to

133. Cf. Faik, The New States and International Legal Order, 18 REcuetL ves Couks (forthcoming).

134. On jurisprudential basis see Faik, On the Quasi-Legislative Competence of tho General Assembly, 60 AM. J. INT'L L. 782 (1966).

135. For some consideration of the difficulties that attend regional authorization of the use of force see Falk, Janus Tormented: The International Law of Internal IVar, in INTE'RNATIONAL ASPECTS OF Givil Strife 185, 242.46 (J. Rosenau ed. 1964).

136. On the assumption, of course, of some de facto control and some substantial prospect of eventual success, and subject to the geo-political qualifications of the threc. zone analysis. 
defeat altogether the ideals of self-determination without promoting the kind of world order premised upon the ordering capacities of territorially based sovereign states. To insulate Type III conflicts it is as important to restrict discrimination in favor of the incumbent as it is to improve the process of detecting covert assistance to the insurgent by making it more visible. To do one without the other is to invite Viet Nam-type confrontations throughout the Tertiary Security Zone. I would espouse a foreign policy of Cosmopolitan Isolationism as most suited to the attainment of world order in the Tertiary Security Zone: national military power should be brought to bear, if at all, only after formal authorization by the organized international community. ${ }^{137}$ In my revised system of categorization, then, external assistance beyond status quo levels is only permissible if the intra-state conflict can be shifted from Type III to Type IV.

\section{The State Department Brief: A Further Comment}

Professor Moore explains that the State Department Memorandum of Law was written mainly to deal with the public debate initiated by a widely circulated (and now redrafted) brief of the Lawyers' Committee on American Policy Towards Viet Nam. ${ }^{138}$ As such, it should not be appraised as the full statement of the Government's position. This is undoubtedly true, but it is nevertheless disappointing that when the Department's Legal Adviser enters the public debate, he does so in such an unconvincing manner. Certainly, it does not clarify the discussion to over-clarify the facts or to make complex legal questions appear self-evident. A citizens' white paper in opposition to Government policy is primarily a call for an impartial accounting, it is intentionally and appropriately one-sided; especially in the security area it is impossible to proffer criticism in effective form unless the issues are somewhat overstated. ${ }^{139}$ It is true, as Professor Moore writes, that the Lawyers' Committee first Memorandum emphasized many of the "wrong" issues or stated the "right" issues in the "wrong" way, but it did provoke the Government after a decade of involvement in Viet Nam to make its first serious effort to reconcile United States foreign

137. I have developed this viewpoint in an essay to appear in ADEPT, a litcrary journal published in Houston, Texas.

138. Consultative Council 19-111.

139. Citizens do not have access to classified information, national news coverage is slanted toward affirming foreign policy in periods of crisis, and only clear conclusions will receive attention in press or government; the more balanced scholarly critique will be ignored except, perhaps, by other scholars, but it will not inluence the public debate. 
policy in Viet Nam with our proclaimed commitment to a law-ordered international society. That serious effort was impaired, in my judgment, by defining the issues and maintaining the adversary spirit of the Lawyers' Committee document. In a second round of public debate the Lawyers' Committee has prepared under the auspices of a Consultative Council composed of academicians a reply to the Govern. ment's Memorandum. This reply does focus more directly on the world order issues at stake and does provide the Government with a new intellectual context within which to respond. It is a sign of health for a democratic polity to engage in this sort of a dialogue during the course of a major war; it may be almost unprecedented for citizens to call their own government to account by an appeal to the constraints and institutional procedures of international law. The outcome of this dialogue, as well as its more scholarly analogues, may well shape our perceptions of the requirements of world order so as either to endorse or inhibit American involvements in a series of Viet Nam-type wars in the decades ahead.

\section{On the Constitutionality of Violating International Law}

Professor Moore suggests that there is no legal authority to support a view that the Executive has a Constitutional obligation to obey international law. What is more, he accuses me of advancing a "somewhat monistic argument." I acknowledge my guilt. It appears to me that the Constitution embodies the legal framework within which the Government is entitled to act. The condemnation of aggressive war and the United States' endorsement of the Principles of the Nuremberg Juclgment seem to make adherence to international law a matter of Constitutional necessity. True, there is no established legal doctrine to this effect, but the question is open enough that is seems reasonable to contend that this is the way the Constitution ought to be authoritntively construed. As in domestic affairs, so in foreign affairs, we should remember that it is a Constitution that we are expounding; as the organic law of the society it must be constantly readapted to the needs of nation and its citizenry. No need is more paramount at the present time than to develop a Constitutional tradition of restraint upon the Executive's virtually discretionary power to commit the nation to war of any scope and duration. To insist on Constitutional sources of legal restraint is a part of the wider global need to erode the prerogatives of the sovereign state in the area of war and peace. So long as international society remains decentralized the most effective legal restraints are likely to be self-restraints, those that are applied from within rather 
than from without the sovereign state. For this reason we cannot neglect the Constitutional dimension of an allegedly illegal participation by the United States in the Viet Nam War. And for this reason it seems appropriate for domestic courts to pronounce upon, rather than to evade, such legal challenges as have been presented in the selective service context. ${ }^{140}$

\section{A Comment on Professor Moore's Conclusion}

Professor Moore concludes his article by affirming "that the conflict cannot be meaningfully generalized in black and white terms" and yet proceeds to do so. He acknowledges that "[i]f because of Viet Nam Americans must ask themselves hard questions about the use of national power and the proper goals of foreign policy, the North Vietnamese must ask themselves equally hard questions about the use of force as an instrument of major international change." These two sets of questions as formulated by Professor Moore are not equally hard, nor are they, it is well to add, impartial in tone or content. As expressed throughout Professor Moore's article the United States' failure in his view, may at most involve errors of judgment and lapses of prudence, whereas North Viet Nam's failure consists of committing the most serious possible international delinquency - waging a war of aggression. Such a construction of the adversary positions greatly falsifies, in my judgment, the true situation. An objective interpretation of the war, as sympathetic with the United States contentions as the fact seem to permit, would acknowledge that the conflict in Viet Nam is one in which both sides sincerely, and even reasonably, perceive the other side as the aggressor. Most disinterested interpretations would, in all probability, tend to regard the United States as the sole aggressor, at least with regard to carrying the war into North Vietnamese territory.

The way in which responsibility for the war is distributed is vitally connected with what sorts of steps taken by which side are reasonable preconditions to achieve a negotiated settlement. In this regard when Professor Moore invokes U Thant to support the conclusion that "the Viet Nam was [is] basically a political problem that can only be solved by a political settlement", it seems only reasonable to add that the Secretary General has laid most of the blame upon the United States for prolonging and intensifying the war. In fact, $U$ Thant's precondi-

140. See the important dissenting opinion of Mrr. Justice Douglas in the decision by the Supreme Court to deny a petition for a writ of certiorari in Afitchell v. United States, 35 U.S.L.TV. 3330 (1967). 
tions for a negotiated settlement include the prior termination of war acts by the United States against North Vietnamese territory.

A second point of disagreement. Professor Moore writes as if the United States and North Viet Nam are in a position of bargaining parity. Such a predisposition not only overlooks the enormous disparity in scale between the two countries, but also overlooks the fact that the United States is fighting the war at a safe distance from its own society, whereas the destructive impact of the conflict is now focused directly upon the North Vietnamese homeland. This bargaining inequality is directly relevant to Profesosr Moore's comments about the "hard line from Hanoi." To advise the United States that it "must continue to emphasize a negotiated settlement" is to write as if no credibility gap existed as to the sincerity and diligence of prior American pence efforts. Such a statement also ignores the extent to which the American emphasis on negotiations has been expressed more through threatened and actual escalations than by realistic offers to end the war on some basis that preserves Hanoi's stake in the outcome to the same extent as it preserves Washington's stake.

It is not possible to consider here the basis for a negotiated settlement. I share Professor Moore's emphasis upon search for compromise in Viet Nam and for a way eventually to give effect to the principle of self-determination for the foresaken Vietnamese population. There are, however, very serious problems with a negotiated settlement that explain, perhaps, why neither side can envision any middle ground between surrender and victory. Among these serious problems the following can be mentioned:

(1) A coalition government in South Viet Nam seems unworkable that either (a) excludes both Premier Ky and the N.L.F., (b) includes Premier Ky but excludes the N.L.F., (c) includes the N.L.F. but excludes Premier Ky, or (d) includes both Premier Ky and the N.L.T. These four alternative patterns exhaust the logical possibilities, and yet no one of them seems to be a plausible basis for a stable South Viet Nam if the war is ended without prior victory by either side;

(2) The negotiating dialogue has stressed bargaining between North Viet Nam and the United States without any close attention being accorded to the more immediately concerned adversaries, namely, the N.L.F. and Saigon. There is no strong basis to believe either that the two external actors can completely impose their will upon the two internal factions or that the two external actors espouse views identical with those held by the two internal factors. Therefore, bargaining toward peace should be broadened at least conceptually to examine the 
positions and leverage of all four major participants in the Viet Nam conflict. An obstacle to this position is the United States' insistence, contrary to widespread neutral and expert interpretation, that the N.L.F. has no identity separate from Hanoi;

(3) The administration of a peaceful settlement in South Viet Nam must find a way to define what constitutes "infiltration" and what constitutes foreign military intervention. These conceptions are even hard to define and even harder to administer effectively. Is an ethnic "Southerner" an infiltrator when he returns unarmed from North to South Viet Nam? By what criteria? Can the regime in Saigon purchase or receive military equipment from outside states as it wishes? Can the government in Hanoi? What criteria can be developed to limit foreign participation in a post-cease-fire environment in Viet Nam? Can a means be found to apply these criteria on a non-political basis? The Geneva machinery of 1954, with its International Control Commission, operates on a troika principle (Poland, Canada, and India) with each rival ideological orientation holding a veto. Would either side be willing to eliminate its own veto or to allow a veto to its adversary? If not, can a mutually acceptable basis for impartial administration be agreed upon?

These are some of the tough questions that beset the search for a negotiated settlement. Their answer is obviously worth seeking. A solution may rely upon substituting an all-Asian presence, possibly under Japanese initiative, for the Western presence that has dominated Vietnamese society since the Nineteenth Century (except for the equally tragic interlude during World War II).

\section{A Concluding Unscientific Postscript}

The extra-legal setting of the United States involvement in Viet Nam is essential if a serious attempt is to be made to rethink the foreign policy premises that have led to this long and painful involvement. If it is correct that we have been led into a costly and unjust war in Viet Nam by ignoring our real interests in world affairs, then it is important to explain how this came about. In the context of a discussion of the relevance of international law, the main contention is that a fairminded attention to the restraints and procedures of the international legal order would have served and continue to serve the real interests of the United States to a far greater extent than do policies arrived at by calculating short-term national advantage purely in terms of maximizing national power, wealth, and prestige. In Viet Nam, the American attempt to control the political outcome to accord with its geo- 
political preferences (regardless of world order consequences) requires an altogether disproportionate commitment even if one approves of the objective sought.

Such a disproportionality suggests that our policy-making process is not being rationally focused upon our "real national interests" in world affairs. This lack of focus seems to arise from a sort of rigidity that comes from endorsing an ideological interpretation of contemporary international conflict. This endorsement takes precedence over world order considerations in American foreign policy and is likely to lead us into future Viet Nams unless it is repudiated. Ideological opposition to Communism and Communist influence as the main premise for military commitment is more dangerous than discredited foreign policies based on the pursuit of wealth and power. At least the policies of conquest left the victor with tangible gains and the prospect of tangible gain allowed for a rational calculation of the proportionality of means and ends. But in the circumstances of a Viet Nam, precisely because the putative gains are intangible-even sacrificial-there is no way to conclude that it costs too much. To question this reasoning it is necessary to be explicit about its relevance. Therefore, to convey my own sense about bringing United States foreign policy into a closer appreciation of its real interests, including a greater deference to the constraints and procedures of international law, it seems useful to carry the legal analysis beyond the boundaries of law and world order. Hence, an unscientific postscript that is at once an explication of the wider orientation of United States foreign policy and a plea for its reorientation.

The United States Government contends that it has no selfish motives in Viet Nam. As President Johnson explained:

We're not trying to wipe out North Vietnam. We're not trying to change their government. We're not trying to establish permanent bases in South Vietnam. And we're not trying to gain one inch of new territory for America. ${ }^{141}$

This absence of selfish motives does not establish the beneficial quality of the American involvement in Viet Nam. The United States pursues its military course in Viet Nam because it is determined to defeat a Communist-led insurgency that sprung up years ago in South Viet Nam as a consequence of many domestic and international factors, only one of which was encouragement from and support by North Viet Nam.

141. President Johnson's Address to the American Alumni Council, N.Y. Timcs, July 18, 1966, at 2 , col. 3 . 
The United States acts as if the war in South Viet Nam was a consequence solely of aggression from the North.

In actuality, the war in South Viet Nam is being waged in a complex post-colonial setting wherein pressures for national self-assertion interact with ideological movements. Many Vietnamese are concerned with attaining their nationhood unencumbered by foreign domination. The United States is opposing revolutionary nationalism, as well as Communism, in South Viet Nam. And the United States is fighting on behalf of a native regime dominated by a reactionary military elite; Premier Ky was a mercenary pilot for the French in both the Algerian War of Independence and the First Indochina War and identifies himself with the politics of military dictatorship.

To wage war for or against an idea is no less destructive than to embark upon conquest for territory or for treasure. Over a century ago John Stuart Mill warned about the use of military power in the service of an idea:

We have heard something lately about being willing to go to war for an idea. To go to war for an idea, if the war is aggressive, not defensive is as criminal as to go to war for territory or revenue. ${ }^{142}$

Ideological motivation may indeed be intense. Its roots are often hidden in the past. We embarked upon a program to resist Communism in 1947 with the formulation of the Truman Doctrine. ${ }^{143}$ Such a program, at that time, was closely and sensibly related to certain geopolitical realities. The Soviet Union was ruled by a military dictator and it maintained tight control over Communist states and parties elsewhere. Western Europe was still weak from World War II. The colonial system was in its early stages of disintegration. Global Communism was a reality to be resisted and feared, although the Communist adversary was cautious, itself badly stunned and damaged by World War II. Since 1947 many changes have taken place, not least of which is the development of nuclear weapons and their deployment in a posture of mutual deterrence. The Soviet Union has followed an increasingly conservative foreign policy and its domestic society has been the scene of progressive liberalization. The Communist group of states has fallen into conflict, and many rather disjoined national varieties of Communism have emerged. Communism is today often a species of nationalism, not internationalism. Western Europe has recovered fully. Its main states are prosperous and stable.

142. J. S. Minl, Essays on Polmtios and Culture 405 (G. Himmelfarb ed. 1962).

143. For a persuasive comprehensive analysis of the evolution of the United States foreign policy response to Communism, see D. Horowrrz, Frosi Yalta to Vietniar (1965). 
Despite these changes in the international setting the United States has not significantly altered its dogmatic opposition to Communism. In Viet Nam President Johnson is carrying forward the basic policies of prior Administrations. ${ }^{144}$ These policies center upon the assumption that it is always adverse to United States interests to allow a society to become identified as "Communist." To call a movement "Communist" that can also draw upon the revolutionary nationalism of a society, as both the Vietcong and Hanoi can, is to overlook one real base of political potency. Viet Nam, unlike other Asian states, is a country where Communist leadership under Ho Chi Minh has for several decades commanded almost all of the forces of anti-colonialism and nationalism. To resist these forces is to become allied with reactionary elements in the society. Unaided, these reactionary elements would have no prospect of prevailing over a popularly based nationalist movement, whether or not it is Communist led. To defeat such a nationalist movement, if at all, presupposes an enormous foreign effort on behalf of the renctionary faction, an effort of the sort the United States has been making on behalf of successive reactionary regimes in Saigon. The result for South Viet Nam is, at best, a dependence that entails a new subservience to an alien Western power. Certainly the United States has introduced more military might into Viet Nam than the French ever used to dominate the country during the colonial period. To have allowed a Vietcong victory and a possible subsequent reunification of Viet Nam under Hanoi's auspices would have merely ratified the process of self-determination internal to Viet Nam that evolved since the early efforts against the French. Such a nationalist solution even if Communist in form would not have posed any serious danger to Western interests and certainly not to direct United States security interests. Viet Nam has a long tradition of fearing and resisting Chinese domination, and there is every reason to suppose that this tradition would persist in a Communist era. The non-Communist neighbors of Viet Nam have, with the possible exception of Laos, stable govern* ments and strong capabilities to maintain internal security.

144. "There is an American consensus on foreign affairs, and the Johnson Administration may legitimately argue that its programs carry out in action what the country de. mands in principle. . . Mr. Johnson escalated the war in Vietnam, but so did Mr. Kennedy when he altered the American commitment in that country from one of assistance and counsel to the South Vietnamese government to direct, if still limited, military engagement with the Vietnamese insurgents. So did Mr. Eisenhower 'escalate,' or more properly, inaugurate, the American involvement when, in 1954, he stepped into the rolc the exhausted French abandoned and chose to sponsor and sustain a noncommunist government in Saigon that would prevent the country's unification under the communist Viet Minh movement which had led the war to expel the French." E. STILLAisN \& W. PFAFF, supra note 99, at 4. 
The United States has made an utterly unconvincing appeal to principles of world order; it purports to be resisting aggression in South Viet Nam. Such a contention is without any firm factual base, but its allegation in a circumstance of ambiguity allows the United States Government to maintain its war effort without admitting its true motivation, thereby confusing its supporters and angering its opponents. As Ralph K. White, an American psychologist who has made an unemotional study of the basis for perceiving aggression in Viet Nam writes: "There has been no aggression on either side-at least not in the sense of a cold-blooded, Hitler-like act of conquest. The analogies of Hitler's march into Prague, Stalin's takeover of Eastern Europe, and the North Korean attack on South Korea are false analogies." White also documents his conclusion that "aggression by us seems as obvious to them as aggression by them seems to us."145

One trouble with fighting for an idea is that there is no way to measure how much sacrifice its defense is worth. An absolutism sets in. The image of the enemy that justifies his destruction is held secure against prudence, reason, and morality. Only clear inferences of Communism, of aggression, and of good intentions vindicate the death and destruction inflicted upon Viet Nam. The United States can maintain these clear inferences only by denying reality or by testing reality in the same primitive way that the Aztecs justified their belief that the corn on which their civilization depended would not grow unless there were human sacrifices. "The fact that the corn did grow was probably considered solid evidence for such a view; and in those years when the harvest was bad, it was doubtless argued that the gods were angry because the sacrifices had been insufficient. A little greater military effort would result, a few more hearts would be torn from their quivering bodies, and the following year it was highly probable that the harvest would be better and the image consequently confirmed."140 Kenneth Boulding regards primitive reasoning of this kind as the way we sustain our commitment in Viet Nam-that is "by appeals to analogy, selfevidence, and to the principle that if at first you don't succeed try more of the same until you do."147 We are entrapped in a dangerous, selfdestructive myth in Viet Nam, the elimination of which can only be sought after the relief of peace, if then. Now we can only justify the sacrifices we have already made by increasing them to the point where

145. White, Misperception of Aggression in Tietnam, $21 \mathrm{~J}$. INT'L Afrans 123, 125 (1907). 146. Boulding, The Learning and Reality-Testing Process in the International System, $21 \mathrm{~J}$. INT'L AFFAIRS I (1967).

147. Id. 2. 
we hope its objective will be reached, regardless of the cost to ourselves and to Viet Nam.

Finally, there is "the credibility gap." Not only is the inference of aggression needed to enable the use of a rhetoric of legitimacy in describing the American efforts in Viet Nam, but the objective of these efforts is disguised. We proclaim over and over again our search for a negotiated settlement, the sincerity of which Professor Moore endorses, and yet we accompany this search by ever-higher escalation and by pre-conditions that by mid-1967 must be interpreted to entail surrender by the adversary. President Johnson writes to Ho Chi Minh that he is "prepared to order a cessation of bombing against your country and the further augmentation of United States forces in South Viet Nam as soon as I am assured that infiltration into South Viet Nam by land and by sea has stopped." 148 How could the Vietcong maintain itself at this stage without supplies and equipment from the North? The effect of Johnson's proposal is to suggest that United States military effort in the South cannot be matched by Northern aid to the N.L.F.: it is to compel the other side to act as if it had been the aggressor. Ho Chi Minh's rejection of such an offer had to be expected. Only a combined disposition by Hanoi and the N.L.F. to call off the insurgency would seem acceptable, only a victory for American power and a defeat for its adversary made militarily possible, if at all, because we are not fighting against Communism, but only against the relatively beleaguered small Communist state of North Viet Nam.

This note in conclusion is an attempt to provide a political setting for the world order claims that the United States has made on behalf of its action in Viet Nam. Without a sense of this setting any appraisal of the legal issues at stake is ultimately without its proper context. Since it is "we" who are perceiving the aggression in Viet Nam, it is essential to know why our understanding of the war is not shared by people elsewhere. Only after making an ideological jail-break and thereafter rediscovering our real values and our interests at home and abroad can we avoid future Viet Nams. I am convinced that we will look back upon the war in Viet $\mathrm{Nam}$ as the greatest tragedy ever in American foreign policy, as a deviation from American political traditions that will appear comprehensible in retrospect only because, in Mill's phrase, we were "willing to go to war for an idea."

148. For the texts of President Johnson's letter (dated Feb. 2, 1967) and President Ho Chi Minh's reply (dated Feb. 15, 1967), see N.Y. Times, March 22, 1966, at 10, col, 2. 


\section{The Yale Law Journal}

Volume 76, Number 6, May 1967

\author{
Editor-in-Chief \\ Note \& Comment \\ Editors
}

Projects Editor

Article \& Book

Review Editors

Topics Editor

Managing Editor

Bruce A. ACrerican

Richard Ayres

LEONARD H. BECKER

JAMES T. BETTS

STEPHEN V. BOMSE

Russell Carpenter

ALLAN Ghapin

RICHARD CoTtoN

Barry G. Craig

John Daum

Marvin J. Diamiond

ARDEN DOSS, JR.

GEOFFREY DRURY

VIRGINIA B. EISENSTEIN

RICHARD A. EPSTEIN

John Miles Evans

W. JOHN GLANCY

RICHARD GOODYEAR

Thomsas Grey

Julian Dean Heller

David W. Hess
LEONARD Mr. Ross

H. JeFF Greenfierd

SIMSON LAZARUS III

JOSEPH N. ONER

SILAS WASSERSTROM

Mitehael S. WaId

IEONARD ChazeN

PhILIP Gordon Schrag

Chardes H. Herz

Thomas Hamilton Childers, Jr.

\author{
LEONARD RUDINOWITZ \\ ThOMAS SCARLETT \\ MLARK SCHANTZ \\ ERIC SCHNAPPER \\ DAVID SCHOENBrod \\ JOHN E. SCHULZ \\ AlaN D. SIsitsky \\ Aluman G. SperLINic \\ Jaxies G. Spethi \\ Mighael T. Stapleto: \\ JOEL TW. STERNALAN \\ Edward L. Strolidem, Jr. \\ Romert B. TanNer \\ David T. Tillotson \\ Gary C. Walker \\ Charles H. Thuitedread II \\ HardY TWieting, JR. \\ JEFEREY WOOD \\ HeNry L. WOodward \\ RODERT JAMIES WOOLSE;, JR. \\ MAATTHEW ZWERLINC
}

\section{Business Secretaries M. Olive Butrerfield, Ether Mortarty}

Student Contributors to This Issue

Russell H. Carpenter, Jr., Civil Commitment of Narcotic Addicts

Arden Doss, Jr., Should Shareholders be Personally Liable for the Torts of Their Corporations?

Thomas Hamilton Childers, Jr., Rational Classification Problems in Financing

State and Local Government

Matthew Zwerling, Welfare's "Condition X"

Christopher May, Withdrawal of Public Welfare: The Right to a Prior Hearing 